\title{
Role of Vitamin D Beyond the Skeletal Function: A Review of the Molecular and Clinical Studies
}

\author{
Meenakshi Umar, Konduru S. Sastry and Aouatef I. Chouchane * \\ Division of Translational Medicine, Research Department, Sidra Medicine, P.O. Box 26999 Doha, Qatar; \\ meenakshiumar@gmail.com (M.U.); skonduru@sidra.org (K.S.S.) \\ * Correspondence: achouchane@sidra.org; Tel.: +974-400-37384
}

Received: 8 April 2018; Accepted: 8 May 2018; Published: 30 May 2018

\begin{abstract}
The classical function of Vitamin D, which involves mineral balance and skeletal maintenance, has been known for many years. With the discovery of vitamin D receptors in various tissues, several other biological functions of vitamin D are increasingly recognized and its role in many human diseases like cancer, diabetes, hypertension, cardiovascular, and autoimmune and dermatological diseases is being extensively explored. The non-classical function of vitamin D involves regulation of cellular proliferation, differentiation, apoptosis, and innate and adaptive immunity. In this review, we discuss and summarize the latest findings on the non-classical functions of vitamin D at the cellular/molecular level and its role in complex human diseases.
\end{abstract}

Keywords: vitamin D; non-phosphocalcic action; cellular functions; immune regulation; clinical effect

\section{Introduction}

Vitamin D is a secosteroid whose function was long considered to be the maintenance of bones and calcium/phosphorous homeostasis. In the last few decades, the extra-skeletal effects of vitamin D became apparent and its effect on the cellular proliferation, differentiation, and immune modulation has been profoundly investigated. Furthermore, reports of protective effects from vitamin D in several diseases like hypertension, diabetes, cardiovascular diseases, autoimmune diseases, and cancers indicate a significant upturn in its role beyond the well-known anti-rachitic factor [1]. In this review, we will comprehensively review the non-classical function of vitamin D with emphasis on its molecular and clinical aspects.

\section{Vitamin D: Sources and Metabolism}

Vitamin D occurs in two major forms, which includes vitamin D2 (ergocalciferol) and vitamin D3 (cholecalciferol). Vitamin D2 is synthesized by ultraviolet B (UVB) irradiation of the ergosterol found in yeast and fungi and it is present in a small number of natural foods (such as UVB-radiated mushrooms), in fortified food, and supplements [2]. On the other hand, vitamin D3 is obtained by photochemical reaction in the skin and through diet via intake of animal-based foods (like cod liver oil and oily fish).

The major source of vitamin D is UVB radiation-induced photochemical and thermal conversion of 7-dehydrocholestrol in the skin. Absorption of UVB radiation $(290-315 \mathrm{~nm})$ in the skin results in the opening of ring B of 7-dehydrocholestrol, which forms a thermodynamically unstable pre-vitamin D3 (9,10-secosterol). This thermally isomerizes into more stable vitamin D3 (cholecalciferol). Vitamin D either formed in the skin or was absorbed from the diet in the small intestine and was transported to the liver. In the liver, vitamin D is hydroxylated by vitamin D 25-hydroxylase (CYP2R1) to produce 25 -hydroxy vitamin $\mathrm{D}(25(\mathrm{OH}) \mathrm{D})$ or calcidiol, which is the accepted biomarker for vitamin D status [3,4]. 25(OH)D is then transported to the kidneys where it is further hydroxylated by 
1- $\alpha$-hydroxylase (CYP27B1) to produce its biologically active form 1- $\alpha$-25-dihydroxy vitamin $\mathrm{D}$ $(1,25(\mathrm{OH}) 2 \mathrm{D}$, also known as calcitriol). Vitamin $\mathrm{D}$ and its metabolites are transported to the target cells primarily by binding to the vitamin D binding protein (DBP). Furthermore, 25(OH)D and $1,25(\mathrm{OH})_{2} \mathrm{D}$ are metabolically inactivated through hydroxylation by 24-hydroxylase (CYP24A1). The vitamin D level in serum is closely regulated through feedback loops involving the actions of calcium, phosphorous, $1,25(\mathrm{OH})_{2} \mathrm{D}$, parathyroid hormone $(\mathrm{PTH})$, and fibroblast growth factor $3[5,6]$. According to the guidelines of US Endocrine Society, the serum levels of 25(OH)D below $20 \mathrm{ng} / \mathrm{mL}$ $(50 \mathrm{nmol} / \mathrm{L})$ are stated as vitamin D deficiency while 25(OH)D serum levels between $21-29 \mathrm{ng} / \mathrm{mL}$ $(52.5-72.5 \mathrm{nmol} / \mathrm{L})$ are defined as vitamin D insufficiency [7]. For subjects with serum 25(OH)D levels between 20 and $21 \mathrm{ng} / \mathrm{mL}$, it is generally accepted that values of serum 25(OH)D levels below $20.5 \mathrm{ng} / \mathrm{mL}$ are taken as $20 \mathrm{ng} / \mathrm{mL}$ and, therefore, considered vitamin D deficiency while serum 25(OH)D levels $\geq 20.5 \mathrm{ng} / \mathrm{mL}$ are taken as $21 \mathrm{ng} / \mathrm{mL}$ and considered to be vitamin D insufficient.

\section{Non-Phosphocalcic Action of Vitamin D}

For many years, the function of vitamin D pro-hormone was considered to be limited to calcium and phosphorus homeostasis. However, after the discovery of vitamin D receptors (VDR) in various cell types (like keratinocytes, lymphocytes, parathyroid and pituitary gland cells, pancreatic cells, etc.), many biological roles of vitamin $\mathrm{D}$ have been revealed in addition to its known actions in classic target tissues [8,9]. The non-classical function of vitamin D includes the regulation of several physiological processes like cell proliferation, differentiation, and immune modulation. Vitamin D mediates its function by binding to the VDR, which is a member of nuclear hormone receptors superfamily. VDR activated by vitamin $\mathrm{D}$ interacts with retinoid $\mathrm{X}$ receptor to form a heterodimeric complex, which is recruited to the vitamin D response elements (VDRE) in the target genes to activate or to repress their expression through interaction with additional co-regulators.

\subsection{Cellular Proliferation and Differentiation}

Vitamin D affects the cellular proliferation by modulating different processes including apoptosis, cell cycle progression, and differentiation in a cell specific manner. It can affect the cell proliferation either directly through binding of VDR (activated by ligand binding) to the response element in the genes regulating cell growth or indirectly by influencing key transcriptional regulators or cell signaling molecules involved in apoptosis, the cell cycle, and differentiation.

\subsubsection{Cell Cycle}

Vitamin D is most commonly reported to repress cell cycle progression by causing cell cycle arrest at G0-G1 transition in a cell specific manner. In many cell lines, $1,25(\mathrm{OH})_{2} \mathrm{D} 3$ induced cyclin dependent kinases inhibitors (CDKIs) expression like p27kip1 and p21WAF1/CIP1 to mediate cell cycle arrest [10-14]. Vitamin D compounds are also reported to alter other regulatory proteins of the cell cycle like INK4, p53, and p21-activated kinase. In addition, calcitriol was found to decrease cyclin D1 and cyclin D3 levels in the MCF-7 breast cancer cell line $[15,16]$ and cyclin E expression in MG-63 osteosarcoma cell line [17], which, in turn, caused inhibition of CDK activity and retinoblastoma protein hypo-phosphorylation. Contrary to the widely reported cell cycle arrest at G0-G1 stage, two reports suggested that vitamin D can mediate cell cycle arrest at later stages: at the G2/M stage by induction of GADD45a in ovarian cancer cell lines and at the G1 stage in the human adrenocortical carcinoma cell line H295R [18,19].

\subsubsection{Differentiation}

Vitamin D and its analogs regulate the differentiation of many malignant/benign tumor cells and also normal cells. Abe et al. reported that $1,25(\mathrm{OH})_{2} \mathrm{D} 3$ stimulates the differentiation of cultured mouse myeloid leukemia cells to macrophages [20]. Similarly, Halline et al., showed that $1,25(\mathrm{OH})_{2} \mathrm{D} 3$ promotes the differentiation and stimulates the formation and maturation of an apical 
microvillus membrane in human intestinal Caco-2 cells [21]. EB1089, which is a vitamin D analog, promoted the differentiation and reversed the malignant phenotype of squamous carcinoma cells, SCC25, by inducing several differentiation-promoting epithelial genes (like Cystatin $M$, Protease $M$, Type XIII collagen, and Desmoglein 3) [22]. Similarly, vitamin D compounds showed an inhibitory effect ontriple negative breast cancer by downregulating key markers of breast cancer stem cells and by upregulating myoepithelial differentiating markers (cytokeratin 14 and smooth muscle actin) [23]. In cardiac cells and colorectal micro-adenoma, vitamin D promoted differentiation through inhibition of Wnt signaling [24,25].

\subsubsection{Apoptosis}

Vitamin D can modulate key mediators of apoptosis in many cancer cell lines and normal cells. Vitamin D triggers apoptosis mainly by inhibiting the anti-apoptotic proteins and/or by stimulating the pro-apoptotic proteins. In human squamous cell carcinoma, inecalcitol (a vitamin $\mathrm{D}$ analog) induced apoptosis by activating the caspase 8/10-caspase 3 pathway and by inhibiting anti-apoptotic proteins like cellular inhibitor of apoptosis protein-1 (c-IAP1) and X-linked inhibitor of apoptosis protein (XIAP) [26]. However, $1,25(\mathrm{OH})_{2}$ D3 lowered the expression of B-cell lymphoma (BCL) protein 2 (BCL2) and B-cell lymphoma-extra large (BCL- $\mathrm{X}_{\mathrm{L}}$ ) mRNA and increased the expression of Bcl-2-associated X (BAX) and p21 mRNA to promote apoptosis of the chronic myeloid leukemia cell line K562 [27]. Similarly, Diaz et al., showed that the vitamin D analog EB1089, through upregulation of BCL2 antagonist killer (BAK), stimulates apoptosis in many colon cancer cell lines [28]. In human retinoblastoma-derived $Y 79$ cells, 1,25(OH $)_{2} \mathrm{D} 3$ and its synthetic analog $\mathrm{KH} 1060$ promoted apoptosis by increasing the BAX protein and reducing BCL2 protein levels [29]. Vitamin D can also trigger apoptosis by mechanisms other than the action on the BCL2 protein family. Sergeev et al., showed that $1,25(\mathrm{OH})_{2} \mathrm{D} 3$ induces $\mathrm{Ca}^{2+}$ signal in breast cancer cells and adipocytes, which directly recruits $\mathrm{Ca}^{2+}$-dependent apoptotic effectors, calpain, and caspase 12 to initiate apoptosis [30]. In another study, vitamin D analogs EB1089 and CB1093 promoted apoptosis in breast cancer cells by suppressing insulin-like growth factor 1 (IGF1) signaling [31]. In kidney cancer cells, it has been shown that vitamin D3 promotes apoptosis by activating forkhead box O3 (FOXO3) through downregulation of phosphorylated serine-threonine protein kinase Akt and extracellular signal-regulated kinase (Erk) [32]. In contrast to the above literature, few reports suggested an inhibitory effect of vitamin D on apoptosis $[33,34]$.

\subsection{Vitamin D and Immune Regulation}

The immune-modulatory action of vitamin D originated from two main observations: (i) the presence of VDR in proliferating immune cells and (ii) the ability of immune cells to metabolize vitamin D [35]. The latter function ensures a physiological high concentration of active $1,25(\mathrm{OH})_{2} \mathrm{D} 3$ in a local lymphoid environment, which promotes its specific action and limits any undesirable high concentration-related systemic effects like hypercalcemia and bone resorption [36]. Locally produced vitamin D acts on immune cells either in intracrine, autocrine, and/or paracrine fashion and affects multiple components of innate and adaptive immunity pathways.

\subsubsection{Vitamin $\mathrm{D}$ and Innate Immunity}

Vitamin D affects this component of the immune system through its action on anti-microbial peptides synthesis and antigen presentation.

\section{Synthesis of Anti-Microbial Peptides (AMP)}

Antimicrobial peptides are low molecular weight host defense peptides with a broad spectrum antimicrobial activity against bacteria, viruses, and fungi. Cathelicidin and defensin are two major groups of epidermal anti-microbial peptides (AMPs), which are reported to be induced by vitamin $\mathrm{D}$ in the immune cells and in a variety of other cells outside the classical immune system. 
Wang et al., showed that treatment of $1,25(\mathrm{OH})_{2} \mathrm{D} 3$ leads to robust induction of cathelicidin in neutrophils, monocytes, human keratinocytes, SCC25 (head and neck squamous carcinoma cells), Calu-3 (lung adenocarcinoma cells), and U937 (myelomonocytic cells) [37]. Similarly, in another study, $1,25(\mathrm{OH})_{2} \mathrm{D} 3$ and its analogs were reported to induce cathelicidin expression in acute myeloid leukemia (AML) cell line, keratinocyte, colon cancer cell lines, and in macrophages derived from bone marrow of AML patients/controls [38]. It was also shown that vitamin D moderately increases the expression of another AMP $\beta$-defensin 2 in some human cell lines (like SCC25, Calu-3 cells, and primary cultures of adult keratinocyte) and this effect is enhanced in the presence of interleukin 1 (IL-1) [37]. Cathelicidin is a direct transcriptional target of vitamin $\mathrm{D}$, which is induced by binding of $1,25(\mathrm{OH})_{2} \mathrm{D} 3-\mathrm{VDR}$ complex to the VDRE in the promoter of the gene. However, $\beta$-defensin 2 requires nuclear kappa B (NF- $\mathrm{kB}$ ) along with $1,25(\mathrm{OH})_{2} \mathrm{D} 3-\mathrm{VDR}$ complex for its transcription [39].

\section{Antigen Presentation}

Antigen presenting cells (APC) of the innate immune system stimulate the lymphocytes of adaptive immunity through antigen presentation to remove the infectious agents. Dendritic cells (DCs) are the most potent APC and are broadly classified into two subtypes based on their origin including myeloid DCs (mDCs) and plasmacytoid DCs (pDCs). 1,25(OH $)_{2} \mathrm{D} 3$ and its analogs are reported to inhibit the maturation, differentiation, and survival of DCs [40,41]. In addition, studies showed that treatment of $1,25(\mathrm{OH})_{2} \mathrm{D} 3$ inhibits the antigen presentation by DCs and primes cells towards tolerogenic state [42,43]. In accordance with this, Penna et al., showed that treatment of $1,25(\mathrm{OH})_{2} \mathrm{D} 3$ maintains the immature phenotype of DCs (marked by low mannose receptors and low CD38 expression) and prevents stimulation of co-stimulatory molecules (CD40, CD80, and CD86) and major histocompatibility complex (MHC) class II protein expression in DCs by reducing its capacity to activate alloreactive T cells [44]. Vitamin D3 also inhibits immune-stimulatory cytokine IL-12 secretion [45] and increases the production of immune-suppressive cytokine IL-10 by DCs [44]. The overall effect of vitamin D treatment on DC is the decrease in T helper 1 (Th1) cell response. The induction of IL-10 produces regulatory $\mathrm{T}$ (Treg) cells and promotes immune tolerance. Studies investigating the effect of vitamin D on DCs subtypes showed that it selectively induces tolerogenic properties in mDCs despite comparable VDR signal transduction in both subtypes [46,47].

\subsubsection{Vitamin $\mathrm{D}$ and Adaptive Immunity}

The adaptive immune system shows an antigen-specific immune response and mediates its effect via $\mathrm{T}$ and B cells. Early studies have demonstrated the expression of VDR in B and T lymphocytes particularly in an immunologically active state [48-50]. Vitamin D can have either an indirect effect on lymphocytes through paracrine signaling by APC (as discussed earlier) or a direct effect by VDR signaling. Several studies indicated that $1,25(\mathrm{OH})_{2} \mathrm{D} 3$ suppresses $\mathrm{T}$ lymphocytes proliferation most likely by reducing IL-2 transcription [51-54]. The effect of vitamin D on different components of adaptive immunity is described in the following sections.

\section{$\mathrm{CD} 4^{+} \mathrm{T}$ Cells}

$\mathrm{CD}^{+} \mathrm{T}$ cells, also known as $\mathrm{T}$ helper (Th) cells, recognize peptides presented by MHC Class II molecules of APC. Based on the pattern of cytokines secreted, they are classified into Th1, Th2, recently identified Th17 cells, Th22, and Treg cells. In many in-vitro studies, $1,25(\mathrm{OH})_{2} \mathrm{D} 3$ inhibited the secretion of interferon gamma (IFN- $\gamma$ ) by $\mathrm{CD}^{+} \mathrm{T}$ cells including Th1 cells [55-58]. Vitamin D3 was also reported to stimulate the development of Th2 cells mainly by increasing the synthesis of IL-4 [57-59]. However, few studies have observed either no effect or repressive effect on IL-4 secretion by vitamin D3 [60-62]. It has also been shown that $1,25(\mathrm{OH})_{2} \mathrm{D} 3$ reduces the expression of IL-17, which is the prototype cytokine of Th17 cells $[56,60,63,64]$. The production of IL-22 (which may be a product of Th17 cells or Th22 cells) is also decreased by $1,25(\mathrm{OH})_{2} \mathrm{D} 3[63,65]$. Similarly, a study showed 
that oral intake of cholecalciferol (daily escalation starting from 2000 up to 8000 IU daily for 12 weeks) resulted in significantly decreased frequencies of IFN- $\gamma^{+}$and /or IL- $17^{+} \mathrm{CD} 4^{+}$Th cells [66].

\section{CD8 ${ }^{+} \mathrm{T}$ Cells}

$\mathrm{CD}^{+} \mathrm{T}$ cells, also known as cytotoxic $\mathrm{T}$ cells, recognize the peptides presented by MHC class I molecules, which are present on all nucleated cells. $\mathrm{CD}^{+} \mathrm{T}$ cells have the highest level of VDR expression compared to other immune cells [49]. Vitamin D3 reduces the proliferation of CD8 ${ }^{+} \mathrm{T}$ cells. VDR knockout $(\mathrm{KO}) \mathrm{CD}^{+} \mathrm{T}$ cells exhibit an increased proliferation without antigen stimulation because of an increased production of IL-2 [61,67,68]. Vitamin D3 deficiency is supposed to augment the gastrointestinal inflammation through its effect on CD8 $\alpha \alpha$ cells. Yu et al., showed that VDR KO mice present with a decreased number of CD8 $\alpha \alpha$ cells (with low level of IL-10) and with an increased inflammatory response [69]. Some studies have investigated the influence of vitamin D3 on the expression of cytokines secreted by CD8 ${ }^{+} \mathrm{T}$ cells like IL-6, IL-12, tumor necrosis factor alpha (TNF- $\alpha$ ), IL-5, and transforming growth factor beta (TGF- $\beta$ ). Willheim et al., suggested an increased frequency of IL- 6 positive and a reduced number of IL-12 positive CD8 ${ }^{+} \mathrm{T}$ cells in cultures with $1,25(\mathrm{OH})_{2} \mathrm{D} 3$ [61]. In addition, Lysandropoulos et al., showed that $1,25(\mathrm{OH})_{2} \mathrm{D} 3$ - treated $\mathrm{CD}^{+} \mathrm{T}$ cells secret less IFN- $\gamma$ and TNF- $\alpha$ and more IL-5 and TGF- $\beta$ [70].

Regulatory T (Treg) cells

Treg cells are a subset of $\mathrm{T}$ cells that suppress the immune response and mediate immune tolerance. These cells are most widely characterized either as naturally occurring $\mathrm{CD} 4{ }^{+} \mathrm{CD} 25^{+} \mathrm{T}$ cells (associated with Forkhead box P3 (Foxp3) transcription factor) or as antigen-driven inducible Treg cells (iTreg). iTreg cells are further categorized into IL-10-producing Treg (Tr1) and TGF- $\beta$ secreting Treg (Th3) cells [71]. 1,25(OH) ${ }_{2} \mathrm{D} 3$ not only enhances IL-10 secretion by $\mathrm{CD} 4^{+} \mathrm{T}$ cells but also increases the frequency of IL-10 producing Treg cells $[57,60,62,72]$. Similarly, $1,25(\mathrm{OH})_{2} \mathrm{D} 3$ treatment was shown to promote the development of Foxp $3^{+} \mathrm{CD}^{+} \mathrm{T}$ cells $[56,73,74]$. In addition, a strong positive correlation was found between Foxp3 ${ }^{+} \mathrm{T}$ cells and the serum 25(OH)D level in patients with asthma, multiple sclerosis, and Behcet disease, which points to the role of vitamin $\mathrm{D}$ in the induction or activation of Treg cells [75-77].

\section{Natural Killer T (NKT) Cells}

NKT cells are specialized $\mathrm{T}$ lymphocytes that play an important role in autoimmunity, cancer, and infections. They are initial up-regulators of IL-4, IFN- $\gamma$, and other cytokines during infection [78]. Studies showed that VDR and its ligand vitamin D regulate the normal development and function of invariant NKT cells (iNKT, a variant of NKT cells) [79,80]. It was also observed that the iNKT cells isolated from VDR knock out mice do not function well and secret less IL-4 and IFN- $\gamma$ [79]. Waddell et al., suggested that $1,25(\mathrm{OH})_{2} \mathrm{D} 3$ mediates a protective effect in autoimmune encephalomyelitis (EAE) through NKT [81]. He demonstrated that 1,25(OH)2D3 treatment failed to prevent the development of EAE in the NKT knock out mice model while it protected wild type mice (which develops EAE on control diet) from developing EAE by affecting NKT specific IL-4 secretion [81].

\section{B Cells}

B cells are antibody-secreting cells of the immune system. Resting B cells express very low levels of VDR, which is upregulated upon activation with various stimuli [82-84]. 1,25(OH) $)_{2} \mathrm{D} 3$ inhibits the proliferation and promotes the apoptosis of activated B cells $[82,85]$. Additionally, $1,25(\mathrm{OH})_{2} \mathrm{D} 3$ was observed to inhibit plasma cell generation and memory B cell formation [82]. Subsequently, the secretion of immunoglobulins IgG and IgM by activated B cells is also shown to be inhibited by vitamin D3 treatment in many in-vitro studies [82-85]. Experimental studies suggest that the calcitriol treatment can reduce IgE synthesis by activated B cells and can lower serum IgE level in 
the type 1 allergy mouse model [86,87]. However, observational studies on the relationship between vitamin D3 and IgE conflict. Certain studies showed an inverse relationship between serum IgE and $25(\mathrm{OH})_{2} \mathrm{D} 3$ levels while others showed a positive correlation. In addition, a nonlinear U-shaped association between vitamin $\mathrm{D}$ and serum IgE levels was suggested by other experts [88-91]. Vitamin D also regulates another relatively small subset of B cells known as regulatory B (Breg) cells. Breg cells are involved in immunological tolerance by producing IL-10, IL-35, and TGF- $\beta$ cytokines. In an in-vitro study, $1,25(\mathrm{OH})_{2} \mathrm{D} 3$ treatment significantly augmented the production of IL-10 by activating B cells [92]. However, in a cross-sectional study, no correlation was observed between vitamin D status and the frequency of Breg cells in multiple sclerosis patients [93].

\section{Molecular and Clinical Studies of Vitamin D in Various Diseases}

The widespread effect of vitamin $\mathrm{D}$ on different physiological processes and the association of vitamin D deficiency to various disorders point towards the potential therapeutic role of this molecule. A randomized double blind clinical trial showed that vitamin D supplementation in vitamin D-deficient subjects significantly affects the expression of genes involved in pathways linked to cancer, auto-immune disorders, and cardiovascular diseases [94]. In this section, we will summarize the findings of several molecular and clinical studies by investigating the role of vitamin $\mathrm{D}$ in diverse health disorders.

\subsection{Cancer}

Vitamin D exerts a beneficial effect on cancer by inhibiting the proliferation, angiogenesis, and metastasis of cancer cells and by promoting the differentiation and apoptosis of these cells. $\mathrm{Li}$ et al., showed that vitamin D3 inhibits the proliferation of gastric cancer cells by stimulating p21 and suppressing CDK2 [95]. Similarly, in melanoma cell lines, vitamin D3 treatment mediated an anti-proliferative effect and modulated the expression of key cell cycle regulatory molecules like p21, p27, cyclin D1, and cyclin A1 [96]. The anti-metastatic activities of vitamin D is thought to be mediated by its ability to downregulate the proteases that promote the degradation of the extracellular matrix (like matrix metalloproteinases (MMP9 and MMP13), and cathepsin) and by its capacity to upregulate the protease inhibitors (like tissue inhibitor of metalloproteinase 1 (TIMP-1) and cathepsin inhibitor) that inhibit the degradation of the extracellular matrix [97,98]. Vitamin D is reported to regulate angiogenesis in several ways [99] including several in vitro and in vivo studies that have shown calcitriol downregulates proangiogenic factors like Hypoxia inducible factor 1 and its response proteins including vascular endothelial growth factor (VEGF) in many cancers [100,101]. Another way vitamin $\mathrm{D}$ regulates angiogenesis is through NF- $\mathrm{kB}$ signaling, which induces angiogenic factors (like IL-8 and VEGF) and was suppressed by vitamin D in prostate cancer cells [102]. Additionally, it was demonstrated that calcitriol may inhibit angiogenesis in some cancers through suppression of prostaglandin pathways [103]. Recently, vitamin D compounds have also been shown to inhibit cancer stem cells by down regulating cancer stem cell markers (like OCT4, CD44, and LAMA5) and by inhibiting Notch signaling molecules (involved in cancer stem cell maintenance). This suggests an additional mechanism through which vitamin $D$ mediates its beneficial role in cancer metastasis and treatment resistance $[23,104]$. The pro-apoptotic and pro-differentiating actions of vitamin D in cancer cells are discussed in detail in Sections 3.1.2 and 3.1.3.

Similar to experimental studies, most of the epidemiological studies have suggested a beneficial effect of vitamin D in cancer risk, incidence, and mortality. A data from pooled analysis of randomized clinical trials (RCT) and prospective cohort studies suggested that $25(\mathrm{OH}) \mathrm{D}$ serum concentrations $\geq 40 \mathrm{ng} / \mathrm{mL}$ are associated with a significant reduction in the risk of many invasive cancers [105]. Similarly, another prospective cohort study stated that vitamin D levels $\geq 30 \mathrm{ng} / \mathrm{mL}$ are associated with a lower risk of tobacco-related cancers in smokers [106]. In observational trials of breast cancer, serum $25(\mathrm{OH}) \mathrm{D}$ levels were positively associated with lower rates of incident breast cancer particularly among postmenopausal women. These levels were inversely correlated with an aggressive form of 
the disease in pre-menopausal and postmenopausal women [107,108]. Furthermore, meta-analyses of cohort studies had shown better survival of breast cancer with high serum 25(OH)D status [109,110]. In colorectal cancer, a 19-year prospective study reported an inverse correlation between dietary vitamin D and calcium intake and the risk of colorectal cancer [111].

Clinical trials investigating the effect of vitamin D supplementation on the cancer incidence yielded contrasting results. In a randomized, double-blind, placebo-controlled, 7-year Women health initiative (WHI) trial, vitamin D and calcium supplementation (1 g calcium + 400 IU vitamin D3 daily) showed no effect on overall incidence of invasive cancers in postmenopausal women [112,113]. However, in post-hoc subgroup analysis, the supplementation was associated with reduced risk of total, breast, and colorectal cancers (in patients not using calcium and vitamin D supplements at baseline) and with decreased risk of melanoma (in women with history of non-melanoma skin cancer) [114,115]. Similarly, in another four-year, double blind, placebo-controlled randomized clinical trial, calcium and vitamin D supplementation (1.5 g calcium + 2000 IU vitamin D3 daily) did not lower the risk of all types of cancers (excluding non-melanoma skin cancers) [116]. A recently published double-blind, placebo-controlled RCT in colorectal adenoma has shown that the beneficial effect of vitamin D3 supplementation varies with VDR genotypes. This includes with reduced risk of advanced adenoma in individuals with VDR rs7968585 AA genotype and with increased risk of advanced adenoma in individuals with VDR rs7968585 GG/GA genotypes [117]. Meta-analysis of RCTs on vitamin D supplementation observed very little influence of vitamin D supplementation (400-1100 IU/day for two to seven years) on cancer incidence, but stated its significant role in reducing the total cancer mortality rate [118].

\subsection{Diabetes}

\subsubsection{Type 1 Diabetes (T1D)}

Experimental studies have indicated the beneficial role of vitamin D in Type 1 Diabetes. Derakhshanian et al., have shown that vitamin D significantly improved fasting glucose, insulin, and IGF-1 in the type 1 diabetes (T1D) rat model [119]. Similarly, vitamin D treatment was shown to enhance the insulin secretion and to suppress the apoptosis of pancreatic $\beta$-cells in the T1D mice model [120]. Ysmail-Dahlouk et al., suggested that the beneficial effect of vitamin D on T1D could be mediated by its anti-inflammatory actions like up-regulation of IL-4, IL-10, arginase activity, and p-STAT6 and down-regulation of IFN- $\gamma$, IL-17, NO, and p-STAT4 levels [121]. In accordance with the previous study, Mao et al., have shown that calcitriol supplementation downregulated serum and urinary inflammation markers like TNF- $\alpha$, IL-6, and ICAM-1 in T1D patients [122].

The observational studies investigating the relation between vitamin D and T1D are inconsistent. However, a meta-analysis of these studies suggests that vitamin D intake during early life is associated with lower risk of T1D [123-125]. The effect of vitamin D supplementation on pancreatic $\beta$-cell functions also varies across different studies and the literature about the role of vitamin D repletion on the glycemic control in T1D patients is scarce and shows contradictory findings [126,127]. Few clinical trials have observed that vitamin $D$ and its analogs either preserved the $\beta$-cell function or led to a slow decline of residual $\beta$-cell function in children with T1D and adults with latent autoimmune diabetes [128-131]. In contrast, other studies did not find any role of vitamin D supplementation on $\beta$-cell functions in T1D patients [132,133]. An RCT studied the effect of vitamin D3 supplementation on Treg cells in T1D patients and reported an improved suppressor capacity of Treg cells in the treatment group (70 IU/Kg bodyweight of cholecalciferol daily) when compared to the placebo group [134].

\subsubsection{Type 2 Diabetes (T2D)}

Similar to T1D animal studies, paricalcitol (a vitamin D analog) treatment in type 2 diabetes (T2D) rats significantly decreased the plasma glucose and insulin resistance by modulating the pancreatic oxidative stress and the inflammatory markers (like C-peptide, adiponectin, pancreatic IL-2, catalase, 
superoxide dismutase, glutathione peroxidase, and TNF- $\alpha$ ) [135]. Elseweidy et al., showed that the administration of vitamin $\mathrm{D}$ in diabetic rats reduced the insulin-degrading enzyme and activated the insulin receptor phosphorylation, which improved the glycemic index and insulin resistance [136].

The results from observational studies suggest that a low vitamin D level increases the risk of hyperglycemia in diabetic and non-diabetic subjects [137]. Additionally, some clinical trials including meta-analysis showed that vitamin D supplementation significantly improves the glycemic control and the metabolic parameters in pre-diabetic and diabetic patients [138-141]. A similar positive effect of vitamin D supplementation was observed in gestational diabetic patients [142]. It was also shown that T2D subjects with specific genotypes (VDR-Cdx-2AA) respond better to vitamin D supplementation [143]. A recent meta-analysis of RCTs suggests that vitamin D supplementation improves the chronic low-grade inflammation in T2D patients by reducing the $\mathrm{C}$ reactive protein level, TNF- $\alpha$ level, and the erythrocyte sedimentation rate by enhancing the leptin level [144]. However, in several other studies, no effect of vitamin D supplementation on $\beta$-cell function, insulin sensitivity, or glycemic outcomes in pre-diabetic or diet-treated diabetic patients was observed [126,145-148]

\subsection{Hypertension and Cardiovascular Diseases}

\subsubsection{Hypertension}

Renin-angiotension system (RAS) is a key regulator of blood pressure, electrolytes, and volume homeostasis. Its abnormal activation is a major risk factor for hypertension and cardiac disease. It has been demonstrated that $1,25(\mathrm{OH})_{2} \mathrm{D} 3$ regulates RAS by reducing renin expression in a VDR-mediated mechanism [149]. Similarly, Carrara et al., have shown that the restoration of a normal vitamin D level resulted in the inhibition of peripheral RAS system and improvement of endothelial function in hypertensive patients with low vitamin D [150]. Studies using renal arteries from hypertensive patients reported that calcitriol reduced the expression of the angiotensin-1 receptor in endothelial cells, which improved endothelial function and prevented reactive oxygen species (ROS) overproduction [151].

Many epidemiological studies have also shown an inverse association between serum vitamin $\mathrm{D}$ levels and the risk of hypertension [152-154]. However, most of the RCTs did not reciprocate similar findings and suggested no significant effect of vitamin D supplementation on blood pressure in hypertensive subjects [155-158]. However, the role of vitamin D supplementation in hypertension based on RCT studies cannot be completely negated as certain studies showed its positive effect in reducing blood pressure either in a particular-group of patients like type 2 diabetic subjects and dark-skinned hypertensive patients and as an adjuvant therapy in grade I-II hypertensive subjects [159-161].

\subsubsection{Cardiovascular Diseases}

Molecular studies have indicated a beneficial role of vitamin D in cardiovascular diseases by regulating thrombosis, atherosclerosis, endothelial function, RAS, vascular calcification, and cardiac hypertrophy. It has been shown that vitamin $\mathrm{D}$ and its analogs prevent the thrombosis by down regulating pro-thrombotic factors like vascular smooth muscle cells derived tissue factor, PAR-2, plasminogen activator inhibitor-1, and thrombospondin and by up-regulating the anti-thrombotic factor thrombomodulin [162,163]. The anti-inflammatory action of vitamin D in endothelial cells was shown to prevent the initiation or the progression of atherosclerosis $[164,165]$. Furthermore, it was also suggested that vitamin D could prevent atherosclerosis by inhibiting the transformation of macrophages to foam cells and by inducing vessel relaxation [166-168]). The role of vitamin D in cardiac hypertrophy was shown in studies on VDR knockout mice and $25(\mathrm{OH}) \mathrm{D}-1-\alpha$-hydroxylase knockout mice, which displayed myocardial hypertrophy $[169,170]$. Vitamin D exerts this anti-hypertrophic effect in many ways such as by suppressing pro-hypertrophic calcineurin/nuclear factor of activated T cells (NFAT)/ myocyte-enriched calcineurin-interacting protein 1 (MCIP1) pathway [171], by inhibiting cardiac RAS system [172], and by inhibiting cardiomyocytes proliferation [173]. The effect of vitamin D on vascular calcification is complex. 
It may increase the vascular calcification through its action on mineral metabolism and promotion of osteoblastic gene expression while it may reduce the vascular calcification through its interaction with fibroblast growth factor 23 (FGF-23) and klotho [168].

In observational studies, low vitamin D status was found to be associated with increased rates of cardiovascular risk factors, with more severe coronary artery disease, and a poor prognosis in patients with heart failure [174-177]. Additionally, some RCTs have indicated a beneficial effect from vitamin D supplementation as an adjuvant therapy on these latter conditions [178-180]. Recently, a meta-analysis showed an inverse relationship between serum 25(OH)D levels and events/mortality of cardiovascular diseases [181]. However, many RCTs did not find any obvious effect of vitamin D supplementation on cardiovascular risk factors in hypertensive patients, premenopausal women, or coronary artery disease subjects and did not show any effect of vitamin D supplementation on the markers of vascular function in myocardial infarction patients [155,182-184]. Similarly, treatment of postmenopausal women with calcium (1000 mg of elemental calcium daily) and vitamin D3 (400 IU daily) did not modify their coronary artery calcified plaque burden [185].

\subsection{Auto-Immune Diseases}

The immunomodulatory actions of vitamin D indicate its important role as a therapeutic agent in autoimmune diseases. It is suggested that vitamin D deficiency may promote autoimmunity by favoring the disproportionate production of Th17 and Th9 cells [186].

\subsubsection{Multiple Sclerosis (MS)}

Vitamin D treatment in multiple sclerosis (MS) patients reduced the proliferation of CD4 ${ }^{+} \mathrm{T}$ cells and myelin basic protein specific T cells, decreased the frequency of IL-6 and IL-17 secreting cells, and promoted the development of IL-10 secreting cells and CD4 ${ }^{+} \mathrm{CD} 25^{+} \mathrm{T}$ regulatory cells $[60,187]$. Furthermore, vitamin D is reported to specifically interact with HLA-DRB1*1501 haplotype (the strongest genetic risk factor of MS) and to influence its expression through VDRE. The latter is consistently expressed in homozygous carriers of HLA-DRB1*1501 [188].

Similarly, several epidemiological studies have shown the association of low serum vitamin D level and low intake of vitamin D with a higher risk of MS $[189,190]$. Many studies suggested that vitamin D supplementation, as an addition for therapy to IFN- $\beta$, shows a beneficial effect on MS and Relapsing-Remitting MS (RRMS) patients. Vitamin D treatment (including its analog, alfacalcidiol) in MS/RRMS patients resulted in a significant improvement in mental quality of life, reduction in MRI disease activity, and low frequency of relapses [191-193]. Additionally, the vitamin D-treated group had higher proportion of relapse-free patients compared to the placebo group [192]. It was also observed that vitamin D supplementation limits the titers of antibodies against the Epstein-Barr virus with the latter increased after the onset of the disease in MS patients [194]. In contrast to these positive findings, most reports suggest no effect of vitamin D on the clinical outcomes of the RRMS or MS patients $[195,196]$.

\subsubsection{Systemic Lupus Erythematosus (SLE)}

Hypovitaminosis D is common in systemic lupus erythematosus (SLE)patients and is usually associated with higher disease activity $[197,198]$ pointing to a potential beneficial role of vitamin D supplementation on SLE patients. Furthermore, in juvenile SLE, cholecalciferol supplementation (50,000 IU/week) for 24 weeks significantly decreased the disease activity and also improved fatigue scores [199]. Similarly, in another study, vitamin D intake (2000 IU/day for 12 months) in SLE patients improved the inflammatory and hemostatic marker levels and reduced disease activity [200]. The beneficial effect of vitamin D on SLE may be due to its ability to expand Treg cells and to its capacity to reduce the frequencies of Th1 cells, Th17 cells, memory B cells, and auto-antibodies [201]. 


\subsubsection{Rheumatoid Arthritis (RA)}

Molecular studies have suggested that vitamin D deficiency in rheumatoid arthritis (RA) stimulates the inflammatory response and promotes the osteoclast-mediated bone resorption [202]. Additionally, vitamin D treatment exhibited an anti-inflammatory response in RA by downregulating IL-6-and TNF- $\beta$ and through enhanced differentiation of Treg and Breg cells. Furthermore, it has been demonstrated that vitamin $\mathrm{D}$ inhibited the osteoclastogenesis and bone resorption in RA by downregulating RANKL and upregulating its decoy receptor osteoprotegerin [202,203]. Epidemiological studies suggest that vitamin D deficiency is common in RA patients. However, its relationship with the disease activity is not clear [204,205]. Reports on the influence of vitamin D supplementation on RA are not consistent. While two open blind studies observed a significant effect of vitamin D repletion on pain relief and disease activity [206,207], others did not demonstrate any role of vitamin D supplementation on the clinical parameters of RA patients [208].

\subsubsection{Auto-Immune Thyroid Diseases (AITD)}

Animal studies have shown that the vitamin D treatment either prevents the development of experimental autoimmune thyroiditis or improves the inflammatory status of the gland by ameliorating the structural changes and normalizing the auto antibody production and the cytokines levels in experimental autoimmune thyroiditis animal models. Vitamin D treatment lowered IFN- $\gamma$ and IL-12 and increased IL-4 and IL-10 levels [209,210]. In addition, many observational studies have shown a significant association of vitamin $\mathrm{D}$ deficiency with the risk of auto-immune thyroid diseases (AITD) [211-213] and with anti-thyroid antibodies and abnormal thyroid function [214,215]. However, some reports did not find any link between vitamin D deficiency and the risk of AITD including Hashimoto thyroiditis [216-218]. Clinical trials investigating the effect of vitamin D supplementation in AITD are limited and inconclusive. While some of them suggested the significant reduction in thyroid auto-antibodies levels (thyroperoxidase autoantibody (TPO-Ab) and thyroglobulin autoantibody $(\mathrm{Tg} \mathrm{Ab})$ ) and the improvement in thyroid function tests (thyroid-stimulating hormone (TSH) and Free Thyroxine (FT4) levels) with vitamin D supplementation in AITD patients $[219,220]$, others showed no effect of vitamin D treatment on thyroid function and autoimmunity in AITD patients [221].

\subsubsection{Systemic Sclerosis (SSc)}

Vitamin D is supposed to mediate a beneficial effect in SSc by decreasing the fibrosis in different tissues. It was observed that VDR expression is decreased in lesional skin, in fibroblasts of systemic sclerosis (SSc) patients, and in fibroblasts of animal models of SSc [222]. It was also demonstrated that the downregulation of VDR in SSc patients' fibroblasts and in SSc animal models' fibroblasts occurred in a TGF- $\beta$-dependent manner. Experts suggested that impaired VDR signaling either due to low VDR expression or low vitamin D level might lead to hyperactive TGF- $\beta$ signaling and aberrant fibroblast activation in SSc [222]. Additionally, paracalcitol (an analog of vitamin D) treatment in animal model of SSc was found to restore VDR signaling and to decrease the pro-fibrotic effects of TGF- $\beta$ on fibroblasts.

Hypovitaminosis D seems to be common in SSc patients, which was reported in many observational studies [223-226]. In addition, several case control studies including a meta-analysis study have shown significantly lower vitamin D level in SSc patients compared to controls [227-229]. Some studies have reported a correlation between vitamin D deficiency and clinical features of SSc patients like skin, cardiac, and lung involvement as well as peripheral vascular, kidney, and gastrointestinal damage [227,230-232]. The association of vertebral fracture and osteoporosis with lower levels of vitamin D was also reported in patients with SSc [232]. There are few contradictory studies, which either found no difference in vitamin D levels of SSc patients and controls or showed no association of vitamin D with clinical parameters of SSc $[229,233]$. Clinical trials on supplementation of vitamin D in SSc patients are very scarce. While one study showed a beneficial effect of $1,25(\mathrm{OH})_{2} \mathrm{D} 3$ supplementation in SSc patients [234], another study was inconclusive due to a very small sample size [235]. 


\subsection{Dermatological Diseases}

Vitamin D, which can be synthesized in the skin, regulates several physiological processes in the skin-like proliferation, differentiation, and apoptosis of keratinocytes and maintenance of normal skin barriers and immune system. Vitamin D deficiency has been linked to many skin pathologies. Some of these pathologies are described below.

\subsubsection{Atopic Dermatitis (AD)}

Atopic dermatitis is characterized by a skin barrier dysfunction and immune dysregulation. Studies have suggested that vitamin D may exert a beneficial effect in atopic dermatitis (AD) by normalizing the altered Th1 and Th2 cytokines (like IL-2, IL-4, IL-6, and IFN- $\gamma$ ), upregulating AMP in the skin, and improving the skin barrier function [236,237]. Furthermore, vitamin D treatment can dampen the enhanced IgE response in $\mathrm{AD}$ by lowering the IgE production by human $\mathrm{B}$ cells and suppressing IgE-mediated mast cell activation [238]. Many case-control studies have shown a lower level of vitamin $\mathrm{D}$ in $\mathrm{AD}$ subjects compared to controls and the association of vitamin $\mathrm{D}$ deficiency to a more severe course of the disease [239-241]. In a prospective cohort study, it was observed that vitamin D-deficient individuals have an increased likelihood of developing AD [242]. Additionally, many RCT have observed a significant improvement of disease severity with vitamin D supplementation [243-245].

\subsubsection{Psoriasis}

Vitamin D, through its anti-inflammatory action, has a beneficial effect in Psoriasis. Molecular studies have shown that vitamin D treatment in psoriatic lesions inhibits pDC capacity to induce T-cell proliferation and IFN- $\gamma$ secretion, suppresses the enhanced Th17 pathways, and upregulates the expression of late cornified envelop genes (LCE3B and LCE3C) [246-248]. Vitamin D deficiency seems to be common in psoriatic patients, which was reported in many studies [249,250]. Vitamin D derivatives, used topically, are a mainstay in the treatment of psoriasis. It has been shown that the topical use of vitamin D (calcitriol twice daily for eight weeks) and its analogs (paricalcitol once daily for 12 weeks, maxacalcitol once daily for eight weeks, and becocalcidiol twice daily for eight weeks) is an effective and safe therapy for mild to moderate plaque psoriasis [251-254]. Similarly, maxacalcitol topical ointment twice daily for eight weeks was found to be effective in the management of palmoplantar pustulosis [255]. Many open-labelled clinical studies have also shown the efficacy and safety of vitamin D analogs in the treatment of facial, nail, and scalp psoriasis [256-258].

\subsubsection{Vitiligo}

The protective effect of vitamin $\mathrm{D}$ in vitiligo is thought to be mediated by its anti-oxidative and anti-apoptotic effect on melanocytes. Vitamin D treatment is reported to prevent apoptosis of melanocytes, to enhance the melanogenesis and the tyrosinase content of melanocytes, and to reduce the oxidative stress by decreasing intracellular ROS overproduction, enhancing superoxide dismutase activity, and decreasing the level of malondialdehyde [259,260]. Many studies have shown that vitiligo subjects are either deficient or insufficient in vitamin D, but when compared to controls, the difference is not always statistically significant [261-263]. Clinical studies investigating the effect of topical application of vitamin D and its analogs are contradictory. Some studies have shown the efficacy and safety of calcipotriol or tacalcitol for the treatment of vitiligo alone or as combination therapy [264-266] while others did not find any significant change in re-pigmentation or lesion size in vitiligo patients $[267,268]$.

Recently, a meta-analysis of the studies on the off-label use of topical vitamin D in the treatment of dermatological diseases has recommended the usage of vitamin D for treating various ichthyoses, morphea, pityriasis alba, prurigo nodularis, and polymorphous light eruption and in vitiligo as combination therapy alongside corticosteroids and phototherapy [269]. 


\subsection{Polycystic Ovarian Syndrome (PCOS)}

The vitamin D deficiency is common in polycystic ovarian syndrome (PCOS) [270-272] and the two recent meta-analysis of clinical trials point to the beneficial role of vitamin D in PCOS patients. These meta-analyses observed an improvement in follicular development, menstrual cycle regulation, serum PTH, and triglycerides levels $[273,274]$. Similarly, vitamin D and calcium co-supplementation for eight weeks was found to positively impact the biomarkers of inflammation and oxidative stress in PCOS [275].

Vitamin D repletion in PCOS women was shown to significantly lower the serum VEGF levels or reduce the TGF- $\beta$ bio-availability. Both of them were separately linked to improvements associated with clinical parameters of PCOS [276,277]. However, there are some clinical studies, which showed no significant effect of vitamin D supplementation on anthropometric or metabolic parameters in PCOS women $[278,279]$.

\section{Conclusions}

Apart from its effect on the bone mineral metabolism, vitamin D exhibits an extensive effect on multiple biological processes in humans like cellular proliferation, differentiation, apoptosis, and immune regulations. Epidemiological and molecular studies have indicated the role of vitamin $\mathrm{D}$ in various health disorders ranging from skin diseases, cardiovascular disorders, cancers, the polycystic ovarian syndrome, autoimmune disorders, and many more. However, the results of randomized clinical trials do not echo the positive impact of vitamin D in many human diseases with similar intensity. This could be due to limited sample sizes, differences in ethnicity, variations in vitamin D dosage, and discrepancies in unmeasured confounding principles across different clinical trials. However, inconsistencies between the findings of molecular studies, observational studies, and randomized clinical trials in many human disorders also raise questions about the role of vitamin $\mathrm{D}$ whether it lies in causal pathways of human disorders or whether low vitamin D levels are only a phenomena in human diseases. Given the widespread effect of vitamin D on key biological processes, it seems unfair to consider vitamin D as only a marker of ill health. However, strong evidence supporting the causal relationship between vitamin $\mathrm{D}$ and non-skeletal human disorders is lacking. In the future, well-designed multi-centric clinical trials in large cohorts may provide definitive answers about the causal effect of vitamin D in human diseases and about the effective and safe usage of vitamin $\mathrm{D} /$ its analogs as therapeutics in complex disorders.

Author Contributions: M.U. performed literature search and wrote the manuscript. A.I.C. conceptualized, contributed to the writing, and reviewed the manuscript. K.S.S. critically reviewed the manuscript for intellectual content. All the authors have read and approved the final manuscript.

Acknowledgments: This work was supported by a grant from Sidra Medicine, Qatar.

Conflicts of Interest: Authors declare that there is no conflict of interest.

\section{Abbreviations}

$\begin{array}{ll}\text { AMP } & \text { Anti-microbial peptide } \\ \text { DC } & \text { Dendritic cell } \\ \text { ng } & \text { Nanogram } \\ \text { nmole } & \text { Nanomole } \\ \text { RCT } & \text { Randomized clinical trial } \\ \text { Th cells } & \text { T helper cells } \\ \text { UVB } & \text { Ultraviolet B } \\ \text { VDR } & \text { Vitamin D receptor }\end{array}$

\section{References}

1. Lai, Y.H.; Fang, T.C. The pleiotropic effect of vitamin D. ISRN Nephrol. 2013, 2013, 1-6. [CrossRef] [PubMed] 
2. Japelt, R.B.; Jakobsen, J. Vitamin D in plants: A review of occurrence, analysis, and biosynthesis. Front. Plant Sci. 2013, 4, 136. [CrossRef] [PubMed]

3. Zerwekh, J.E. Blood biomarkers of vitamin D status. Am. J. Clin. Nutr. 2008, 87, 1087S-1091S. [CrossRef] [PubMed]

4. Seamans, K.M.; Cashman, K.D. Existing and potentially novel functional markers of vitamin D status: A systematic review. Am. J. Clin. Nutr. 2009, 89, 1997S-2008S. [CrossRef] [PubMed]

5. Henry, H.L. Regulation of vitamin D metabolism. Best Pract. Res. Clin. Endocrinol. Metab. 2011, 25, 531-541. [CrossRef] [PubMed]

6. Christakos, S.; Ajibade, D.V.; Dhawan, P.; Fechner, A.J.; Mady, L.J. Vitamin D: Metabolism. Endocrinol. Metab. Clin. N. Am. 2010, 39, 243-253. [CrossRef] [PubMed]

7. Holick, M.F.; Binkley, N.C.; Bischoff-Ferrari, H.A.; Gordon, C.M.; Hanley, D.A.; Heaney, R.P.; Murad, M.H.; Weaver, C.M. Evaluation, treatment, and prevention of vitamin D deficiency: An Endocrine Society clinical practice guideline. J. Clin. Endocrinol. Metab. 2011, 96, 1911-1930. [CrossRef] [PubMed]

8. Jones, G.; Strugnell, S.A.; DeLuca, H.F. Current understanding of the molecular actions of vitamin D. Physiol. Rev. 1998, 78, 1193-1231. [CrossRef] [PubMed]

9. Holick, M.F. Vitamin D deficiency. N. Engl. J. Med. 2007, 357, 266-281. [CrossRef] [PubMed]

10. Liu, M.; Lee, M.H.; Cohen, M.; Bommakanti, M.; Freedman, L.P. Transcriptional activation of the Cdk inhibitor p21 by vitamin D3 leads to the induced differentiation of the myelomonocytic cell line U937. Genes Dev. 1996, 10, 142-153. [CrossRef] [PubMed]

11. Wang, Q.M.; Jones, J.B.; Studzinski, G.P. Cyclin-dependent kinase inhibitor p27 as a mediator of the G1-S phase block induced by 1,25-dihydroxyvitamin D3 in HL60 cells. Cancer Res. 1996, 56, 264-267. [PubMed]

12. Jiang, H.; Lin, J.; Su, Z.Z.; Collart, F.R.; Huberman, E.; Fisher, P.B. Induction of differentiation in human promyelocytic HL-60 leukemia cells activates p21, WAF1/CIP1, expression in the absence of p53. Oncogene 1994, 9, 3397-3406. [PubMed]

13. Moffatt, K.A.; Johannes, W.U.; Hedlund, T.E.; Miller, G.J. Growth inhibitory effects of 1- $\alpha$-25-dihydroxyvitamin D3 are mediated by increased levels of p21 in the prostatic carcinoma cell line ALVA-31. Cancer Res. 2001, 61, 7122-7129. [PubMed]

14. Boyle, B.J.; Zhao, X.Y.; Cohen, P.; Feldman, D. Insulin-like growth factor binding protein-3 mediates 1- $\alpha$-25-dihydroxyvitamin D3 growth inhibition in the LNCaP prostate cancer cell line through p21/WAF1. J. Urol. 2001, 165, 1319-1324. [CrossRef]

15. Verlinden, L.; Verstuyf, A.; Convents, R.; Marcelis, S.; Van Camp, M.; Bouillon, R. Action of 1,25(OH)2D3 on the cell cycle genes, cyclin D1, p21 and p27 in MCF-7 cells. Mol. Cell. Endocrinol. 1998, 142, 57-65. [CrossRef]

16. Jensen, S.S.; Madsen, M.W.; Lukas, J.; Binderup, L.; Bartek, J. Inhibitory effects of 1- $\alpha$-25-dihydroxyvitamin D3 on the G1-S phase-controlling machinery. Mol. Endocrinol. 2001, 15, 1370-1380. [CrossRef] [PubMed]

17. Ryhanen, S.; Jaaskelainen, T.; Mahonen, A.; Maenpaa, P.H. Inhibition of MG-63 cell cycle progression by synthetic vitamin D3 analogs mediated by p27, Cdk2, cyclin E, and the retinoblastoma protein. Biochem. Pharmacol. 2003, 66, 495-504. [CrossRef]

18. Jiang, F.; Li, P.; Fornace, A.J., Jr.; Nicosia, S.V.; Bai, W. G2/M arrest by 1,25-dihydroxyvitamin D3 in ovarian cancer cells mediated through the induction of GADD45 via an exonic enhancer. J. Biol. Chem. 2003, 278, 48030-48040. [CrossRef] [PubMed]

19. Pilon, C.; Urbanet, R.; Williams, T.A.; Maekawa, T.; Vettore, S.; Sirianni, R.; Pezzi, V.; Mulatero, P.; Fassina, A.; Sasano, H.; et al. 1- $\alpha$-25-Dihydroxyvitamin D3 inhibits the human H295R cell proliferation by cell cycle arrest: A model for a protective role of vitamin D receptor against adrenocortical cancer. J. Steroid Biochem. Mol. Biol. 2014, 140, 26-33. [CrossRef] [PubMed]

20. Abe, E.; Miyaura, C.; Sakagami, H.; Takeda, M.; Konno, K.; Yamazaki, T.; Yoshiki, S.; Suda, T. Differentiation of mouse myeloid leukemia cells induced by 1- $\alpha$-25-dihydroxyvitamin D3. Proc. Natl. Acad. Sci. USA 1981, 78, 4990-4994. [CrossRef] [PubMed]

21. Halline, A.G.; Davidson, N.O.; Skarosi, S.F.; Sitrin, M.D.; Tietze, C.; Alpers, D.H.; Brasitus, T.A. Effects of 1,25-dihydroxyvitamin D3 on proliferation and differentiation of Caco-2 cells. Endocrinology 1994, 134, 1710-1717. [CrossRef] [PubMed] 
22. Lin, R.; Nagai, Y.; Sladek, R.; Bastien, Y.; Ho, J.; Petrecca, K.; Sotiropoulou, G.; Diamandis, E.P.; Hudson, T.J.; White, J.H. Expression profiling in squamous carcinoma cells reveals pleiotropic effects of vitamin D3 analog EB1089 signaling on cell proliferation, differentiation, and immune system regulation. Mol. Endocrinol. 2002, 16, 1243-1256. [CrossRef] [PubMed]

23. Shan, N.L.; Wahler, J.; Lee, H.J.; Bak, M.J.; Gupta, S.D.; Maehr, H.; Suh, N. Vitamin D compounds inhibit cancer stem-like cells and induce differentiation in triple negative breast cancer. J. Steroid Biochem. Mol. Biol. 2017, 173, 122-129. [CrossRef] [PubMed]

24. Groschel, C.; Aggarwal, A.; Tennakoon, S.; Hobaus, J.; Prinz-Wohlgenannt, M.; Marian, B.; Heffeter, P.; Berger, W.; Kallay, E. Effect of 1,25-dihydroxyvitamin D3 on the Wnt pathway in non-malignant colonic cells. J. Steroid Biochem. Mol. Biol. 2016, 155, 224-230. [CrossRef] [PubMed]

25. Kim, I.M.; Norris, K.C.; Artaza, J.N. Vitamin D and Cardiac Differentiation. Vitam. Horm. 2016, 100, $299-320$. [PubMed]

26. Ma, Y.; Yu, W.D.; Hidalgo, A.A.; Luo, W.; Delansorne, R.; Johnson, C.S.; Trump, D.L. Inecalcitol, an analog of 1,25D3, displays enhanced antitumor activity through the induction of apoptosis in a squamous cell carcinoma model system. Cell Cycle 2013, 12, 743-752. [CrossRef] [PubMed]

27. Kizildag, S.; Ates, H. Treatment of K562 cells with 1,25-dihydroxyvitamin D3 induces distinct alterations in the expression of apoptosis-related genes BCL2, BAX, BCLXL, and p21. Ann. Hematol. 2010, 89, 1-7. [CrossRef] [PubMed]

28. Diaz, G.D.; Paraskeva, C.; Thomas, M.G.; Binderup, L.; Hague, A. Apoptosis is induced by the active metabolite of vitamin D3 and its analogue EB1089 in colorectal adenoma and carcinoma cells: Possible implications for prevention and therapy. Cancer Res. 2000, 60, 2304-2312. [PubMed]

29. Wagner, N.; Wagner, K.D.; Schley, G.; Badiali, L.; Theres, H.; Scholz, H. 1,25-dihydroxyvitamin D3-induced apoptosis of retinoblastoma cells is associated with reciprocal changes of Bcl-2 and Bax. Exp. Eye Res. 2003, 77, 1-9. [CrossRef]

30. Sergeev, I.N. Regulation of apoptosis in adipocytes and breast cancer cells by 1,25-dihydroxyvitamin D3: A link between obesity and breast cancer. Horm. Mol. Biol. Clin. Investig. 2013, 14, 99-106. [CrossRef] [PubMed]

31. Xie, S.P.; Pirianov, G.; Colston, K.W. Vitamin D analogues suppress IGF-I signalling and promote apoptosis in breast cancer cells. Eur. J. Cancer 1999, 35, 1717-1723. [CrossRef]

32. Lee, J.; Park, S.H. Tumor-suppressive activity of 1,25-dihydroxyvitamin D3 against kidney cancer cells via up-regulation of FOXO3. Biosci. Biotechnol. Biochem. 2016, 80, 1947-1953. [CrossRef] [PubMed]

33. De Haes, P.; Garmyn, M.; Carmeliet, G.; Degreef, H.; Vantieghem, K.; Bouillon, R.; Segaert, S. Molecular pathways involved in the anti-apoptotic effect of 1,25-dihydroxyvitamin D3 in primary human keratinocytes. J. Cell. Biochem. 2004, 93, 951-967. [CrossRef] [PubMed]

34. Regulska, M.; Leskiewicz, M.; Budziszewska, B.; Kutner, A.; Jantas, D.; Basta-Kaim, A.; Kubera, M.; Jaworska-Feil, L.; Lason, W. Inhibitory effects of 1,25-dihydroxyvitamin D3 and its low-calcemic analogues on staurosporine-induced apoptosis. Pharmacol. Rep. 2007, 59, 393-401. [PubMed]

35. Chun, R.F.; Liu, P.T.; Modlin, R.L.; Adams, J.S.; Hewison, M. Impact of vitamin D on immune function: Lessons learned from genome-wide analysis. Front. Physiol. 2014, 5, 151. [CrossRef] [PubMed]

36. Mora, J.R.; Iwata, M.; von Andrian, U.H. Vitamin effects on the immune system: Vitamins A and D take centre stage. Nat. Rev. Immunol. 2008, 8, 685-698. [CrossRef] [PubMed]

37. Wang, T.T.; Nestel, F.P.; Bourdeau, V.; Nagai, Y.; Wang, Q.; Liao, J.; Tavera-Mendoza, L.; Lin, R.; Hanrahan, J.W.; Mader, S.; et al. Cutting edge: 1,25-dihydroxyvitamin D3 is a direct inducer of antimicrobial peptide gene expression. J. Immunol. 2004, 173, 2909-2912. [CrossRef] [PubMed]

38. Gombart, A.F.; Borregaard, N.; Koeffler, H.P. Human cathelicidin antimicrobial peptide (CAMP) gene is a direct target of the vitamin D receptor and is strongly up-regulated in myeloid cells by 1,25-dihydroxyvitamin D3. FASEB J. 2005, 19, 1067-1077. [CrossRef] [PubMed]

39. Liu, P.T.; Schenk, M.; Walker, V.P.; Dempsey, P.W.; Kanchanapoomi, M.; Wheelwright, M.; Vazirnia, A.; Zhang, X.; Steinmeyer, A.; Zugel, U.; et al. Convergence of IL-1 $\beta$ and VDR activation pathways in human TLR2/1-induced antimicrobial responses. PLoS ONE 2009, 4, e5810. [CrossRef] [PubMed]

40. Piemonti, L.; Monti, P.; Sironi, M.; Fraticelli, P.; Leone, B.E.; Dal Cin, E.; Allavena, P.; Di Carlo, V. Vitamin D3 affects differentiation, maturation, and function of human monocyte-derived dendritic cells. J. Immunol. 2000, 164, 4443-4451. [CrossRef] [PubMed] 
41. Griffin, M.D.; Lutz, W.H.; Phan, V.A.; Bachman, L.A.; McKean, D.J.; Kumar, R. Potent inhibition of dendritic cell differentiation and maturation by vitamin D analogs. Biochem. Biophys. Res. Commun. 2000, 270, 701-708. [CrossRef] [PubMed]

42. Bartels, L.E.; Hvas, C.L.; Agnholt, J.; Dahlerup, J.F.; Agger, R. Human dendritic cell antigen presentation and chemotaxis are inhibited by intrinsic 25-hydroxy vitamin D activation. Int. Immunopharmacol. 2010, 10, 922-928. [CrossRef] [PubMed]

43. Dam, T.N.; Moller, B.; Hindkjaer, J.; Kragballe, K. The vitamin D3 analog calcipotriol suppresses the number and antigen-presenting function of Langerhans cells in normal human skin. J. Investig. Dermatol. Symp. Proc. 1996, 1, 72-77. [PubMed]

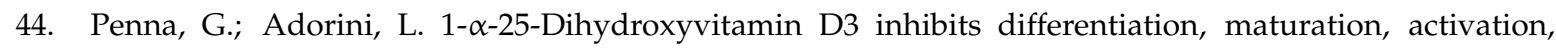
and survival of dendritic cells leading to impaired alloreactive T cell activation. J. Immunol. 2000, 164, 2405-2411. [CrossRef] [PubMed]

45. D’Ambrosio, D.; Cippitelli, M.; Cocciolo, M.G.; Mazzeo, D.; Di Lucia, P.; Lang, R.; Sinigaglia, F.; Panina-Bordignon, P. Inhibition of IL-12 production by 1,25-dihydroxyvitamin D3. Involvement of NF- $\mathrm{KB}$ downregulation in transcriptional repression of the $p 40$ gene. J. Clin. Investig. 1998, 101, 252-262. [CrossRef] [PubMed]

46. Penna, G.; Amuchastegui, S.; Giarratana, N.; Daniel, K.C.; Vulcano, M.; Sozzani, S.; Adorini, L. 1,25-Dihydroxyvitamin D3 selectively modulates tolerogenic properties in myeloid but not plasmacytoid dendritic cells. J. Immunol. 2007, 178, 145-153. [CrossRef] [PubMed]

47. Penna, G.; Amuchastegui, S.; Laverny, G.; Adorini, L. Vitamin D receptor agonists in the treatment of autoimmune diseases: Selective targeting of myeloid but not plasmacytoid dendritic cells. J. Bone Miner. Res. 2007, 22 (Suppl. 2), V69-V73. [CrossRef] [PubMed]

48. Provvedini, D.M.; Tsoukas, C.D.; Deftos, L.J.; Manolagas, S.C. 1,25-Dihydroxyvitamin D3 receptors in human leukocytes. Science 1983, 221, 1181-1183. [CrossRef] [PubMed]

49. Veldman, C.M.; Cantorna, M.T.; DeLuca, H.F. Expression of 1,25-dihydroxyvitamin D3 receptor in the immune system. Arch. Biochem. Biophys. 2000, 374, 334-338. [CrossRef] [PubMed]

50. Yu, X.P.; Mocharla, H.; Hustmyer, F.G.; Manolagas, S.C. Vitamin D receptor expression in human lymphocytes. Signal requirements and characterization by western blots and DNA sequencing. J. Biol. Chem. 1991, 266, 7588-7595. [PubMed]

51. Bhalla, A.K.; Amento, E.P.; Serog, B.; Glimcher, L.H. 1,25-Dihydroxyvitamin D3 inhibits antigen-induced T cell activation. J. Immunol. 1984, 133, 1748-1754. [PubMed]

52. Tsoukas, C.D.; Provvedini, D.M.; Manolagas, S.C. 1,25-Dihydroxyvitamin D3: A novel immunoregulatory hormone. Science 1984, 224, 1438-1440. [CrossRef] [PubMed]

53. Rigby, W.F.; Stacy, T.; Fanger, M.W. Inhibition of T lymphocyte mitogenesis by 1,25-dihydroxyvitamin D3 (calcitriol). J. Clin. Investig. 1984, 74, 1451-1455. [CrossRef] [PubMed]

54. Alroy, I.; Towers, T.L.; Freedman, L.P. Transcriptional repression of the interleukin-2 gene by vitamin D3: Direct inhibition of NFATp/AP-1 complex formation by a nuclear hormone receptor. Mol. Cell. Biol. 1995, 15, 5789-5799. [CrossRef] [PubMed]

55. Staeva-Vieira, T.P.; Freedman, L.P. 1,25-Dihydroxyvitamin D3 inhibits IFN-gamma and IL-4 levels during in vitro polarization of primary murine CD4 ${ }^{+}$T cells. J. Immunol. 2002, 168, 1181-1189. [CrossRef] [PubMed]

56. Jeffery, L.E.; Burke, F.; Mura, M.; Zheng, Y.; Qureshi, O.S.; Hewison, M.; Walker, L.S.; Lammas, D.A.; Raza, K.; Sansom, D.M. 1,25-Dihydroxyvitamin D3 and IL-2 combine to inhibit T cell production of inflammatory cytokines and promote development of regulatory T cells expressing CTLA-4 and FoxP3. J. Immunol. 2009, 183, 5458-5467. [CrossRef] [PubMed]

57. Bartels, L.E.; Jorgensen, S.P.; Agnholt, J.; Kelsen, J.; Hvas, C.L.; Dahlerup, J.F. 1,25-Dihydroxyvitamin D3 and dexamethasone increase interleukin-10 production in $\mathrm{CD}^{+} \mathrm{T}$ cells from patients with Crohn's disease. Int. Immunopharmacol. 2007, 7, 1755-1764. [CrossRef] [PubMed]

58. Mahon, B.D.; Wittke, A.; Weaver, V.; Cantorna, M.T. The targets of vitamin D depend on the differentiation and activation status of CD4 positive T cells. J. Cell. Biochem. 2003, 89, 922-932. [CrossRef] [PubMed]

59. Boonstra, A.; Barrat, F.J.; Crain, C.; Heath, V.L.; Savelkoul, H.F.; O'Garra, A. 1- $\alpha-25-D i h y d r o x y v i t a m i n$ $\mathrm{D} 3$ has a direct effect on naive $\mathrm{CD} 4^{+} \mathrm{T}$ cells to enhance the development of Th2 cells. J. Immunol. 2001, 167, 4974-4980. [CrossRef] [PubMed] 
60. Correale, J.; Ysrraelit, M.C.; Gaitan, M.I. Immunomodulatory effects of Vitamin D in multiple sclerosis. Brain 2009, 132, 1146-1460. [CrossRef] [PubMed]

61. Willheim, M.; Thien, R.; Schrattbauer, K.; Bajna, E.; Holub, M.; Gruber, R.; Baier, K.; Pietschmann, P.; Reinisch, W.; Scheiner, O.; et al. Regulatory effects of 1- $\alpha$-25-dihydroxyvitamin D3 on the cytokine production of human peripheral blood lymphocytes. J. Clin. Endocrinol. Metab. 1999, 84, 3739-3744. [CrossRef] [PubMed]

62. Baeke, F.; Korf, H.; Overbergh, L.; Verstuyf, A.; Thorrez, L.; Van Lommel, L.; Waer, M.; Schuit, F.; Gysemans, C.; Mathieu, C. The vitamin D analog, TX527, promotes a human CD4 ${ }^{+}$CD25highCD127low regulatory $\mathrm{T}$ cell profile and induces a migratory signature specific for homing to sites of inflammation. J. Immunol. 2011, 186, 132-142. [CrossRef] [PubMed]

63. Ikeda, U.; Wakita, D.; Ohkuri, T.; Chamoto, K.; Kitamura, H.; Iwakura, Y.; Nishimura, T. 1- $\alpha$-25-Dihydroxyvitamin D3 and all-trans retinoic acid synergistically inhibit the differentiation and expansion of Th17 cells. Immunol. Lett. 2010, 134, 7-16. [CrossRef] [PubMed]

64. Chang, J.H.; Cha, H.R.; Lee, D.S.; Seo, K.Y.; Kweon, M.N. 1,25-Dihydroxyvitamin D3 inhibits the differentiation and migration of $\mathrm{T}(\mathrm{H}) 17$ cells to protect against experimental autoimmune encephalomyelitis. PLoS ONE 2010, 5, e12925. [CrossRef]

65. Colin, E.M.; Asmawidjaja, P.S.; van Hamburg, J.P.; Mus, A.M.; van Driel, M.; Hazes, J.M.; van Leeuwen, J.P.; Lubberts, E. 1,25-dihydroxyvitamin D3 modulates Th17 polarization and interleukin-22 expression by memory T cells from patients with early rheumatoid arthritis. Arthritis Rheum. 2010, 62, 132-142. [CrossRef] [PubMed]

66. Drozdenko, G.; Heine, G.; Worm, M. Oral vitamin D increases the frequencies of CD38 ${ }^{+}$human B cells and ameliorates IL-17-producing T cells. Exp. Dermatol. 2014, 23, 107-112. [CrossRef] [PubMed]

67. Chen, J.; Bruce, D.; Cantorna, M.T. Vitamin D receptor expression controls proliferation of naive CD8 ${ }^{+}$T cells and development of CD8 mediated gastrointestinal inflammation. BMC Immunol. 2014, 15, 6. [CrossRef] [PubMed]

68. Rigby, W.F.; Yirinec, B.; Oldershaw, R.L.; Fanger, M.W. Comparison of the effects of 1,25-dihydroxyvitamin D3 on T lymphocyte subpopulations. Eur. J. Immunol. 1987, 17, 563-566. [CrossRef] [PubMed]

69. Yu, S.; Bruce, D.; Froicu, M.; Weaver, V.; Cantorna, M.T. Failure of T cell homing, reduced CD4/CD8 $\alpha \alpha$ intraepithelial lymphocytes, and inflammation in the gut of vitamin D receptor KO mice. Proc. Natl. Acad. Sci. USA 2008, 105, 20834-20839. [CrossRef] [PubMed]

70. Lysandropoulos, A.P.; Jaquiery, E.; Jilek, S.; Pantaleo, G.; Schluep, M.; Du Pasquier, R.A. Vitamin D has a direct immunomodulatory effect on $\mathrm{CD}^{+} \mathrm{T}$ cells of patients with early multiple sclerosis and healthy control subjects. J. Neuroimmunol. 2011, 233, 240-244. [CrossRef] [PubMed]

71. Thompson, C.; Powrie, F. Regulatory T cells. Curr. Opin. Pharmacol. 2004, 4, 408-414. [CrossRef] [PubMed]

72. Barrat, F.J.; Cua, D.J.; Boonstra, A.; Richards, D.F.; Crain, C.; Savelkoul, H.F.; de Waal-Malefyt, R.; Coffman, R.L.; Hawrylowicz, C.M.; O'Garra, A. In vitro generation of interleukin 10-producing regulatory $\mathrm{CD}^{+} \mathrm{T}$ cells is induced by immunosuppressive drugs and inhibited by $\mathrm{T}$ helper type 1 (Th1)- and Th2-inducing cytokines. J. Exp. Med. 2002, 195, 603-616. [CrossRef] [PubMed]

73. Urry, Z.; Chambers, E.S.; Xystrakis, E.; Dimeloe, S.; Richards, D.F.; Gabrysova, L.; Christensen, J.; Gupta, A.; Saglani, S.; Bush, A.; et al. The role of 1- $\alpha$-25-dihydroxyvitamin D3 and cytokines in the promotion of distinct Foxp3 ${ }^{+}$and IL-10 ${ }^{+} \mathrm{CD}^{+}$T cells. Eur. J. Immunol. 2012, 42, 2697-2708. [CrossRef] [PubMed]

74. Morales-Tirado, V.; Wichlan, D.G.; Leimig, T.E.; Street, S.E.; Kasow, K.A.; Riberdy, J.M. 1- $\alpha$-25-Dihydroxyvitamin D3 (vitamin D3) catalyzes suppressive activity on human natural regulatory T cells, uniquely modulates cell cycle progression, and augments FOXP3. Clin. Immunol. 2011, 138, $212-221$. [CrossRef] [PubMed]

75. Chambers, E.S.; Nanzer, A.M.; Richards, D.F.; Ryanna, K.; Freeman, A.T.; Timms, P.M.; Martineau, A.R.; Griffiths, C.J.; Corrigan, C.J.; Hawrylowicz, C.M. Serum 25-dihydroxyvitamin D levels correlate with $\mathrm{CD}^{+}{ }^{+}$Foxp3 $^{+}$T-cell numbers in moderate/severe asthma. J. Allergy Clin. Immunol. 2012, 130, 542-544. [CrossRef] [PubMed]

76. Hamzaoui, K.; Ben Dhifallah, I.; Karray, E.; Sassi, F.H.; Hamzaoui, A. Vitamin D modulates peripheral immunity in patients with Behcet's disease. Clin. Exp. Rheumatol. 2010, 28 (Suppl. 60), S50-S57. [PubMed]

77. Smolders, J.; Thewissen, M.; Peelen, E.; Menheere, P.; Tervaert, J.W.; Damoiseaux, J.; Hupperts, R. Vitamin D status is positively correlated with regulatory $\mathrm{T}$ cell function in patients with multiple sclerosis. PLoS ONE 2009, 4, e6635. [CrossRef] [PubMed] 
78. Berzins, S.P.; Uldrich, A.P.; Pellicci, D.G.; McNab, F.; Hayakawa, Y.; Smyth, M.J.; Godfrey, D.I. Parallels and distinctions between T and NKT cell development in the thymus. Immunol. Cell Biol. 2004, 82, 269-275. [CrossRef] [PubMed]

79. Yu, S.; Cantorna, M.T. The vitamin D receptor is required for iNKT cell development. Proc. Natl. Acad. Sci. USA 2008, 105, 5207-5212. [CrossRef] [PubMed]

80. Yu, S.; Cantorna, M.T. Epigenetic reduction in invariant NKT cells following in utero vitamin D deficiency in mice. J. Immunol. 2011, 186, 1384-1390. [CrossRef] [PubMed]

81. Waddell, A.; Zhao, J.; Cantorna, M.T. NKT cells can help mediate the protective effects of 1,25-dihydroxyvitamin D3 in experimental autoimmune encephalomyelitis in mice. Int. Immunol. 2015, 27, 237-244. [CrossRef] [PubMed]

82. Chen, S.; Sims, G.P.; Chen, X.X.; Gu, Y.Y.; Lipsky, P.E. Modulatory effects of 1,25-dihydroxyvitamin D3 on human B cell differentiation. J. Immunol. 2007, 179, 1634-1647. [CrossRef] [PubMed]

83. Provvedini, D.M.; Tsoukas, C.D.; Deftos, L.J.; Manolagas, S.C. 1- $\alpha$-25-Dihydroxyvitamin D3-binding macromolecules in human B lymphocytes: Effects on immunoglobulin production. J. Immunol. 1986, 136, 2734-2740. [PubMed]

84. Iho, S.; Takahashi, T.; Kura, F.; Sugiyama, H.; Hoshino, T. The effect of 1,25-dihydroxyvitamin D3 on in vitro immunoglobulin production in human B cells. J. Immunol. 1986, 136, 4427-4431. [PubMed]

85. Lemire, J.M.; Adams, J.S.; Sakai, R.; Jordan, S.C. 1- $\alpha$-25-Dihydroxyvitamin D3 suppresses proliferation and immunoglobulin production by normal human peripheral blood mononuclear cells. J. Clin. Investig. 1984, 74, 657-661. [CrossRef] [PubMed]

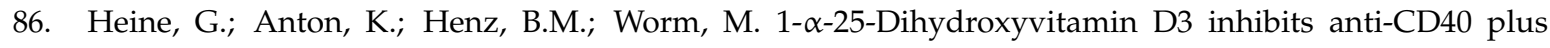
IL-4-mediated IgE production in vitro. Eur. J. Immunol. 2002, 32, 3395-3404. [CrossRef]

87. Hartmann, B.; Heine, G.; Babina, M.; Steinmeyer, A.; Zugel, U.; Radbruch, A.; Worm, M. Targeting the vitamin D receptor inhibits the B cell-dependent allergic immune response. Allergy 2011, 66, 540-548. [CrossRef] [PubMed]

88. Gupta, A.; Sjoukes, A.; Richards, D.; Banya, W.; Hawrylowicz, C.; Bush, A.; Saglani, S. Relationship between serum vitamin $\mathrm{D}$, disease severity, and airway remodeling in children with asthma. Am. J. Respir. Crit. Care Med. 2011, 184, 1342-1349. [CrossRef] [PubMed]

89. Sharief, S.; Jariwala, S.; Kumar, J.; Muntner, P.; Melamed, M.L. Vitamin D levels and food and environmental allergies in the United States: Results from the National Health and Nutrition Examination Survey 2005-2006. J. Allergy Clin. Immunol. 2011, 127, 1195-1202. [CrossRef] [PubMed]

90. Hypponen, E.; Berry, D.J.; Wjst, M.; Power, C. Serum 25-hydroxyvitamin D and IgE-A significant but nonlinear relationship. Allergy 2009, 64, 613-620. [CrossRef] [PubMed]

91. Kang, J.W.; Kim, J.H.; Kim, H.J.; Lee, J.G.; Yoon, J.H.; Kim, C.H. Association of serum 25-hydroxyvitamin D with serum IgE levels in Korean adults. Auris Nasus Larynx 2016, 43, 84-88. [CrossRef] [PubMed]

92. Heine, G.; Niesner, U.; Chang, H.D.; Steinmeyer, A.; Zugel, U.; Zuberbier, T.; Radbruch, A.; Worm, M. 1,25-Dihydroxyvitamin D3 promotes IL-10 production in human B cells. Eur. J. Immunol. 2008, 38, 2210-2218. [CrossRef] [PubMed]

93. Knippenberg, S.; Peelen, E.; Smolders, J.; Thewissen, M.; Menheere, P.; Cohen Tervaert, J.W.; Hupperts, R.; Damoiseaux, J. Reduction in IL-10 producing B cells (Breg) in multiple sclerosis is accompanied by a reduced naive/memory Breg ratio during a relapse but not in remission. J. Neuroimmunol. 2011, 239, 80-86. [CrossRef] [PubMed]

94. Hossein-nezhad, A.; Spira, A.; Holick, M.F. Influence of vitamin D status and vitamin D3 supplementation on genome wide expression of white blood cells: A randomized double-blind clinical trial. PLoS ONE 2013, 8, e58725. [CrossRef] [PubMed]

95. Li, M.; Li, L.; Zhang, L.; Hu, W.; Shen, J.; Xiao, Z.; Wu, X.; Chan, F.L.; Cho, C.H. 1,25-Dihydroxyvitamin D3 suppresses gastric cancer cell growth through VDR- and mutant p53-mediated induction of p21. Life Sci. 2017, 179, 88-97. [CrossRef] [PubMed]

96. Spath, L.; Ulivieri, A.; Lavra, L.; Fidanza, L.; Carlesimo, M.; Giubettini, M.; Narcisi, A.; Luciani, E.; Bucci, B.; Pisani, D.; et al. Antiproliferative Effects of 1- $\alpha-\mathrm{OH}-\mathrm{vitD} 3$ in Malignant Melanoma: Potential Therapeutic implications. Sci. Rep. 2017, 7, 40370. [CrossRef] [PubMed] 
97. Meephansan, J.; Komine, M.; Tsuda, H.; Ohtsuki, M. Suppressive effect of calcipotriol on the induction of matrix metalloproteinase (MMP)-9 and MMP-13 in a human squamous cell carcinoma cell line. Clin. Exp. Dermatol. 2012, 37, 889-896. [CrossRef] [PubMed]

98. Bao, B.Y.; Yeh, S.D.; Lee, Y.F. 1- $\alpha$-25-Dihydroxyvitamin D3 inhibits prostate cancer cell invasion via modulation of selective proteases. Carcinogenesis 2006, 27, 32-42. [CrossRef] [PubMed]

99. Xu, J.; Li, W.; Ma, J.; Liu, J.; Sha, H.; Zhou, S.; Wang, F.; Ma, Q. Vitamin D-Pivotal nutraceutical in the regulation of cancer metastasis and angiogenesis. Curr. Med. Chem. 2013, 20, 4109-4120. [CrossRef] [PubMed]

100. Ben-Shoshan, M.; Amir, S.; Dang, D.T.; Dang, L.H.; Weisman, Y.; Mabjeesh, N.J. 1- $\alpha$-25-Dihydroxyvitamin D3 (Calcitriol) inhibits hypoxia-inducible factor-1/vascular endothelial growth factor pathway in human cancer cells. Mol. Cancer Ther. 2007, 6, 1433-1439. [CrossRef] [PubMed]

101. Mantell, D.J.; Owens, P.E.; Bundred, N.J.; Mawer, E.B.; Canfield, A.E. 1- $\alpha$-25-Dihydroxyvitamin D3 inhibits angiogenesis in vitro and in vivo. Circ. Res. 2000, 87, 214-220. [CrossRef] [PubMed]

102. Bao, B.Y.; Yao, J.; Lee, Y.F. 1- $\alpha$-25-Dihydroxyvitamin D3 suppresses interleukin-8-mediated prostate cancer cell angiogenesis. Carcinogenesis 2006, 27, 1883-1893. [CrossRef] [PubMed]

103. Swami, S.; Krishnan, A.V.; Moreno, J.; Bhattacharyya, R.B.; Peehl, D.M.; Feldman, D. Calcitriol and genistein actions to inhibit the prostaglandin pathway: Potential combination therapy to treat prostate cancer. J. Nutr. 2007, 137, 205S-210S. [CrossRef] [PubMed]

104. So, J.Y.; Lee, H.J.; Smolarek, A.K.; Paul, S.; Wang, C.X.; Maehr, H.; Uskokovic, M.; Zheng, X.; Conney, A.H.; Cai, L.; et al. A novel Gemini vitamin D analog represses the expression of a stem cell marker CD44 in breast cancer. Mol. Pharmacol. 2011, 79, 360-367. [CrossRef] [PubMed]

105. McDonnell, S.L.; Baggerly, C.; French, C.B.; Baggerly, L.L.; Garland, C.F.; Gorham, E.D.; Lappe, J.M.; Heaney, R.P. Serum 25-Hydroxyvitamin D Concentrations $\geq 40 \mathrm{ng} / \mathrm{mL}$ Are Associated with $>65 \%$ Lower Cancer Risk: Pooled Analysis of Randomized Trial and Prospective Cohort Study. PLoS ONE 2016, 11, e0152441. [CrossRef] [PubMed]

106. Deschasaux, M.; Souberbielle, J.C.; Latino-Martel, P.; Sutton, A.; Charnaux, N.; Druesne-Pecollo, N.; Galan, P.; Hercberg, S.; Le Clerc, S.; Kesse-Guyot, E.; et al. Prospective associations between vitamin D status, vitamin D-related gene polymorphisms, and risk of tobacco-related cancers. Am. J. Clin. Nutr. 2015, 102, 1207-1215. [CrossRef] [PubMed]

107. O'Brien, K.M.; Sandler, D.P.; Taylor, J.A.; Weinberg, C.R. Serum Vitamin D and Risk of Breast Cancer within Five Years. Environ. Health Perspect. 2017, 125, 077004. [CrossRef] [PubMed]

108. Buono, G.; Giuliano, M.; De Angelis, C.; Lauria, R.; Forestieri, V.; Pensabene, M.; Bruzzese, D.; De Placido, S.; Arpino, G. Pretreatment Serum Concentration of Vitamin D and Breast Cancer Characteristics: A Prospective Observational Mediterranean Study. Clin. Breast Cancer 2017, 17, 559-563. [CrossRef] [PubMed]

109. Hu, K.; Callen, D.F.; Li, J.; Zheng, H. Circulating Vitamin D and Overall Survival in Breast Cancer Patients: A Dose-Response Meta-Analysis of Cohort Studies. Integr. Cancer Ther. 2017, 1-9. [CrossRef] [PubMed]

110. Kim, Y.; Je, Y. Vitamin D intake, blood 25(OH)D levels, and breast cancer risk or mortality: A meta-analysis. Br. J. Cancer 2014, 110, 2772-2784. [CrossRef] [PubMed]

111. Garland, C.; Shekelle, R.B.; Barrett-Connor, E.; Criqui, M.H.; Rossof, A.H.; Paul, O. Dietary vitamin D and calcium and risk of colorectal cancer: A 19-year prospective study in men. Lancet 1985, 1, 307-309. [CrossRef]

112. Brunner, R.L.; Wactawski-Wende, J.; Caan, B.J.; Cochrane, B.B.; Chlebowski, R.T.; Gass, M.L.; Jacobs, E.T.; LaCroix, A.Z.; Lane, D.; Larson, J.; et al. The effect of calcium plus vitamin D on risk for invasive cancer: Results of the Women's Health Initiative (WHI) calcium plus vitamin D randomized clinical trial. Nutr. Cancer 2011, 63, 827-841. [CrossRef] [PubMed]

113. Wactawski-Wende, J.; Kotchen, J.M.; Anderson, G.L.; Assaf, A.R.; Brunner, R.L.; O'Sullivan, M.J.; Margolis, K.L.; Ockene, J.K.; Phillips, L.; Pottern, L.; et al. Calcium plus vitamin D supplementation and the risk of colorectal cancer. N. Engl. J. Med. 2006, 354, 684-696. [CrossRef] [PubMed]

114. Bolland, M.J.; Grey, A.; Gamble, G.D.; Reid, I.R. Calcium and vitamin D supplements and health outcomes: A reanalysis of the Women's Health Initiative (WHI) limited-access data set. Am. J. Clin. Nutr. 2011, 94, 1144-1149. [CrossRef] [PubMed] 
115. Tang, J.Y.; Fu, T.; Leblanc, E.; Manson, J.E.; Feldman, D.; Linos, E.; Vitolins, M.Z.; Zeitouni, N.C.; Larson, J.; Stefanick, M.L. Calcium plus vitamin D supplementation and the risk of nonmelanoma and melanoma skin cancer: Post Hoc analyses of the women's health initiative randomized controlled trial. J. Clin. Oncol. 2011, 29, 3078-3084. [CrossRef] [PubMed]

116. Lappe, J.; Watson, P.; Travers-Gustafson, D.; Recker, R.; Garland, C.; Gorham, E.; Baggerly, K.; McDonnell, S.L. Effect of Vitamin D and Calcium Supplementation on Cancer Incidence in Older Women: A Randomized Clinical Trial. JAMA 2017, 317, 1234-1243. [CrossRef] [PubMed]

117. Barry, E.L.; Peacock, J.L.; Rees, J.R.; Bostick, R.M.; Robertson, D.J.; Bresalier, R.S.; Baron, J.A. Vitamin D Receptor Genotype, Vitamin D3 Supplementation, and Risk of Colorectal Adenomas: A Randomized Clinical Trial. JAMA Oncol. 2017, 3, 628-635. [CrossRef] [PubMed]

118. Keum, N.; Giovannucci, E. Vitamin D supplements and cancer incidence and mortality: A meta-analysis. Br. J. Cancer 2014, 111, 976-980. [CrossRef] [PubMed]

119. Derakhshanian, H.; Javanbakht, M.H.; Zarei, M.; Djalali, E.; Djalali, M. Vitamin D increases IGF-I and insulin levels in experimental diabetic rats. Growth Horm. IGF Res. 2017, 36, 57-59. [CrossRef] [PubMed]

120. Wang, Y.; He, D.; Ni, C.; Zhou, H.; Wu, S.; Xue, Z.; Zhou, Z. Vitamin D induces autophagy of pancreatic $\beta$-cells and enhances insulin secretion. Mol. Med. Rep. 2016, 14, 2644-2650. [CrossRef] [PubMed]

121. Ysmail-Dahlouk, L.; Nouari, W.; Aribi, M. 1,25-Dihydroxyvitamin D3 down-modulates the production of proinflammatory cytokines and nitric oxide and enhances the phosphorylation of monocyte-expressed STAT6 at the recent-onset type 1 diabetes. Immunol. Lett. 2016, 179, 122-130. [CrossRef] [PubMed]

122. Mao, L.; Ji, F.; Liu, Y.; Zhang, W.; Ma, X. Calcitriol plays a protective role in diabetic nephropathy through anti-inflammatory effects. Int. J. Clin. Exp. Med. 2014, 7, 5437-5444. [PubMed]

123. Hypponen, E.; Laara, E.; Reunanen, A.; Jarvelin, M.R.; Virtanen, S.M. Intake of vitamin D and risk of type 1 diabetes: A birth-cohort study. Lancet 2001, 358, 1500-1503. [CrossRef]

124. Simpson, M.; Brady, H.; Yin, X.; Seifert, J.; Barriga, K.; Hoffman, M.; Bugawan, T.; Baron, A.E.; Sokol, R.J.; Eisenbarth, G.; et al. No association of vitamin D intake or 25-hydroxyvitamin D levels in childhood with risk of islet autoimmunity and type 1 diabetes: The Diabetes Autoimmunity Study in the Young (DAISY). Diabetologia 2011, 54, 2779-2788. [CrossRef] [PubMed]

125. Dong, J.Y.; Zhang, W.G.; Chen, J.J.; Zhang, Z.L.; Han, S.F.; Qin, L.Q. Vitamin D intake and risk of type 1 diabetes: A meta-analysis of observational studies. Nutrients 2013, 5, 3551-3562. [CrossRef] [PubMed]

126. Shih, E.M.; Mittelman, S.; Pitukcheewanont, P.; Azen, C.G.; Monzavi, R. Effects of vitamin D repletion on glycemic control and inflammatory cytokines in adolescents with type 1 diabetes. Pediatr. Diabetes 2016, 17, 36-43. [CrossRef] [PubMed]

127. Aljabri, K.S.; Bokhari, S.A.; Khan, M.J. Glycemic changes after vitamin D supplementation in patients with type 1 diabetes mellitus and vitamin D deficiency. Ann. Saudi Med. 2010, 30, 454-458. [CrossRef] [PubMed]

128. Ataie-Jafari, A.; Loke, S.C.; Rahmat, A.B.; Larijani, B.; Abbasi, F.; Leow, M.K.; Yassin, Z. A randomized placebo-controlled trial of $\alpha$ calcidol on the preservation of $\beta$ cell function in children with recent onset type 1 diabetes. Clin. Nutr. 2013, 32, 911-917. [CrossRef] [PubMed]

129. Gabbay, M.A.; Sato, M.N.; Finazzo, C.; Duarte, A.J.; Dib, S.A. Effect of cholecalciferol as adjunctive therapy with insulin on protective immunologic profile and decline of residual $\beta$-cell function in new-onset type 1 diabetes mellitus. Arch. Pediatr. Adolesc. Med. 2012, 166, 601-607. [CrossRef] [PubMed]

130. Li, X.; Liao, L.; Yan, X.; Huang, G.; Lin, J.; Lei, M.; Wang, X.; Zhou, Z. Protective effects of 1- $\alpha$-hydroxyvitamin D3 on residual $\beta$-cell function in patients with adult-onset latent autoimmune diabetes (LADA). Diabetes Metab. Res. Rev. 2009, 25, 411-416. [CrossRef] [PubMed]

131. Sharma, S.; Biswal, N.; Bethou, A.; Rajappa, M.; Kumar, S.; Vinayagam, V. Does Vitamin D Supplementation Improve Glycaemic Control in Children with Type 1 Diabetes Mellitus?-A Randomized Controlled Trial. J. Clin. Diagn. Res. 2017, 11, SC15-SC17. [CrossRef] [PubMed]

132. Bizzarri, C.; Pitocco, D.; Napoli, N.; Di Stasio, E.; Maggi, D.; Manfrini, S.; Suraci, C.; Cavallo, M.G.; Cappa, M.; Ghirlanda, G.; et al. No protective effect of calcitriol on $\beta$-cell function in recent-onset type 1 diabetes: The IMDIAB XIII trial. Diabetes Care 2010, 33, 1962-1963. [CrossRef] [PubMed]

133. Walter, M.; Kaupper, T.; Adler, K.; Foersch, J.; Bonifacio, E.; Ziegler, A.G. No effect of the 1- $\alpha$-25-Dihydroxyvitamin D3 on $\beta$-cell residual function and insulin requirement in adults with new-onset type 1 diabetes. Diabetes Care 2010, 33, 1443-1448. [CrossRef] [PubMed] 
134. Treiber, G.; Prietl, B.; Frohlich-Reiterer, E.; Lechner, E.; Ribitsch, A.; Fritsch, M.; Rami-Merhar, B.; Steigleder-Schweiger, C.; Graninger, W.; Borkenstein, M.; et al. Cholecalciferol supplementation improves suppressive capacity of regulatory T-cells in young patients with new-onset type 1 diabetes mellitus-A randomized clinical trial. Clin. Immunol. 2015, 161, 217-224. [CrossRef] [PubMed]

135. Ali, T.M.; El Esawy, B.; Elaskary, A. Effect of paricalcitol on pancreatic oxidative stress, inflammatory markers, and glycemic status in diabetic rats. Ir. J. Med. Sci. 2018, 187, 75-84. [CrossRef] [PubMed]

136. Elseweidy, M.M.; Amin, R.S.; Atteia, H.H.; Ali, M.A. Vitamin D3 intake as regulator of insulin degrading enzyme and insulin receptor phosphorylation in diabetic rats. Biomed. Pharmacother. 2017, 85, 155-159. [CrossRef] [PubMed]

137. Rafiq, S.; Jeppesen, P.B. Is Hypovitaminosis D Related to Incidence of Type 2 Diabetes and High Fasting Glucose Level in Healthy Subjects: A Systematic Review and Meta-Analysis of Observational Studies. Nutrients 2018, 10, 59. [CrossRef] [PubMed]

138. Shaseb, E.; Tohidi, M.; Abbasinazari, M.; Khalili, D.; Talasaz, A.H.; Omrani, H.; Hadaegh, F. The effect of a single dose of vitamin D on glycemic status and C-reactive protein levels in type 2 diabetic patients with ischemic heart disease: A randomized clinical trial. Acta Diabetol. 2016, 53, 575-582. [CrossRef] [PubMed]

139. Nimitphong, H.; Samittarucksa, R.; Saetung, S.; Bhirommuang, N.; Chailurkit, L.O.; Ongphiphadhanakul, B. The Effect of Vitamin D Supplementation on Metabolic Phenotypes in Thais with Prediabetes. J. Med. Assoc. Thail. 2015, 98, 1169-1178.

140. Wu, C.; Qiu, S.; Zhu, X.; Li, L. Vitamin D supplementation and glycemic control in type 2 diabetes patients: A systematic review and meta-analysis. Metabolism 2017, 73, 67-76. [CrossRef] [PubMed]

141. Mirhosseini, N.; Vatanparast, H.; Mazidi, M.; Kimball, S.M. The Effect of Improved Serum 25-Hydroxyvitamin D Status on Glycemic Control in Diabetic Patients: A Meta-Analysis. J. Clin. Endocrinol. Metab. 2017, 102, 3097-3110. [CrossRef] [PubMed]

142. Jamilian, M.; Karamali, M.; Taghizadeh, M.; Sharifi, N.; Jafari, Z.; Memarzadeh, M.R.; Mahlouji, M.; Asemi, Z. Vitamin D and Evening Primrose Oil Administration Improve Glycemia and Lipid Profiles in Women with Gestational Diabetes. Lipids 2016, 51, 349-356. [CrossRef] [PubMed]

143. Shab-Bidar, S.; Neyestani, T.R.; Djazayery, A. Vitamin D receptor Cdx-2-dependent response of central obesity to vitamin D intake in the subjects with type 2 diabetes: A randomised clinical trial. Br. J. Nutr. 2015, 114, 1375-1384. [CrossRef] [PubMed]

144. Mousa, A.; Naderpoor, N.; Teede, H.; Scragg, R.; de Courten, B. Vitamin D supplementation for improvement of chronic low-grade inflammation in patients with type 2 diabetes: A systematic review and meta-analysis of randomized controlled trials. Nutr. Rev. 2018, 76, 380-394. [CrossRef] [PubMed]

145. Wagner, H.; Alvarsson, M.; Mannheimer, B.; Degerblad, M.; Ostenson, C.G. No Effect of High-Dose Vitamin D Treatment on $\beta$-Cell Function, Insulin Sensitivity, or Glucose Homeostasis in Subjects With Abnormal Glucose Tolerance: A Randomized Clinical Trial. Diabetes Care 2016, 39, 345-352. [CrossRef] [PubMed]

146. Krul-Poel, Y.H.; Westra, S.; ten Boekel, E.; ter Wee, M.M.; van Schoor, N.M.; van Wijland, H.; Stam, F.; Lips, P.T.; Simsek, S. Effect of Vitamin D Supplementation on Glycemic Control in Patients With Type 2 Diabetes (SUNNY Trial): A Randomized Placebo-Controlled Trial. Diabetes Care 2015, 38, 1420-1426. [CrossRef] [PubMed]

147. Javed, A.; Vella, A.; Balagopal, P.B.; Fischer, P.R.; Weaver, A.L.; Piccinini, F.; Dalla Man, C.; Cobelli, C.; Giesler, P.D.; Laugen, J.M.; et al. Cholecalciferol supplementation does not influence $\beta$-cell function and insulin action in obese adolescents: A prospective double-blind randomized trial. J. Nutr. 2015, 145, 284-290. [CrossRef] [PubMed]

148. Mitchell, D.M.; Leder, B.Z.; Cagliero, E.; Mendoza, N.; Henao, M.P.; Hayden, D.L.; Finkelstein, J.S.; Burnett-Bowie, S.A. Insulin secretion and sensitivity in healthy adults with low vitamin D are not affected by high-dose ergocalciferol administration: A randomized controlled trial. Am. J. Clin. Nutr. 2015, 102, 385-392. [CrossRef] [PubMed]

149. Li, Y.C.; Kong, J.; Wei, M.; Chen, Z.F.; Liu, S.Q.; Cao, L.P. 1,25-Dihydroxyvitamin D3 is a negative endocrine regulator of the renin-angiotensin system. J. Clin. Investig. 2002, 110, 229-238. [CrossRef] [PubMed]

150. Carrara, D.; Bruno, R.M.; Bacca, A.; Taddei, S.; Duranti, E.; Ghiadoni, L.; Bernini, G. Cholecalciferol treatment downregulates renin-angiotensin system and improves endothelial function in essential hypertensive patients with hypovitaminosid D. J. Hypertens. 2016, 34, 2199-2205. [CrossRef] [PubMed] 
151. Dong, J.; Wong, S.L.; Lau, C.W.; Lee, H.K.; Ng, C.F.; Zhang, L.; Yao, X.; Chen, Z.Y.; Vanhoutte, P.M.; Huang, Y. Calcitriol protects renovascular function in hypertension by down-regulating angiotensin II type 1 receptors and reducing oxidative stress. Eur. Heart J. 2012, 33, 2980-2990. [CrossRef] [PubMed]

152. Forman, J.P.; Giovannucci, E.; Holmes, M.D.; Bischoff-Ferrari, H.A.; Tworoger, S.S.; Willett, W.C.; Curhan, G.C. Plasma 25-hydroxyvitamin D levels and risk of incident hypertension. Hypertension 2007, 49, 1063-1069. [CrossRef] [PubMed]

153. Martins, D.; Wolf, M.; Pan, D.; Zadshir, A.; Tareen, N.; Thadhani, R.; Felsenfeld, A.; Levine, B.; Mehrotra, R.; Norris, K. Prevalence of cardiovascular risk factors and the serum levels of 25-hydroxyvitamin D in the United States: Data from the Third National Health and Nutrition Examination Survey. Arch. Intern. Med. 2007, 167, 1159-1165. [CrossRef] [PubMed]

154. Scragg, R.; Sowers, M.; Bell, C. Serum 25-hydroxyvitamin D, ethnicity, and blood pressure in the Third National Health and Nutrition Examination Survey. Am. J. Hypertens. 2007, 20, 713-719. [CrossRef] [PubMed]

155. Pilz, S.; Gaksch, M.; Kienreich, K.; Grubler, M.; Verheyen, N.; Fahrleitner-Pammer, A.; Treiber, G.; Drechsler, C.; Hartaigh, B.Ó.; Obermayer-Pietsch, B.; et al. Effects of vitamin D on blood pressure and cardiovascular risk factors: A randomized controlled trial. Hypertension 2015, 65, 1195-1201. [CrossRef] [PubMed]

156. Arora, P.; Song, Y.; Dusek, J.; Plotnikoff, G.; Sabatine, M.S.; Cheng, S.; Valcour, A.; Swales, H.; Taylor, B.; Carney, E.; et al. Vitamin D therapy in individuals with prehypertension or hypertension: The DAYLIGHT trial. Circulation 2015, 131, 254-262. [CrossRef] [PubMed]

157. Scragg, R.; Slow, S.; Stewart, A.W.; Jennings, L.C.; Chambers, S.T.; Priest, P.C.; Florkowski, C.M.; Camargo, C.A., Jr.; Murdoch, D.R. Long-term high-dose vitamin D3 supplementation and blood pressure in healthy adults: A randomized controlled trial. Hypertension 2014, 64, 725-730. [CrossRef] [PubMed]

158. Witham, M.D.; Price, R.J.; Struthers, A.D.; Donnan, P.T.; Messow, C.M.; Ford, I.; McMurdo, M.E. Cholecalciferol treatment to reduce blood pressure in older patients with isolated systolic hypertension: The VitDISH randomized controlled trial. JAMA Intern. Med. 2013, 173, 1672-1679. [CrossRef] [PubMed]

159. Chen, W.R.; Liu, Z.Y.; Shi, Y.; Yin, D.W.; Wang, H.; Sha, Y.; Chen, Y.D. Vitamin D and nifedipine in the treatment of Chinese patients with grades I-II essential hypertension: A randomized placebo-controlled trial. Atherosclerosis 2014, 235, 102-109. [CrossRef] [PubMed]

160. Bonakdaran, S.; Nejad, A.F.; Abdol-Reza, V.; Hatefi, A.; Shakeri, M. Impact of oral 1,25-dihydroxy vitamin D (calcitriol) replacement therapy on coronary artery risk factors in type 2 diabetic patients. Endocr. Metab. Immune Disord. Drug Targets 2013, 13, 295-300. [CrossRef] [PubMed]

161. Forman, J.P.; Scott, J.B.; Ng, K.; Drake, B.F.; Suarez, E.G.; Hayden, D.L.; Bennett, G.G.; Chandler, P.D.; Hollis, B.W.; Emmons, K.M.; et al. Effect of vitamin D supplementation on blood pressure in blacks. Hypertension 2013, 61, 779-785. [CrossRef] [PubMed]

162. Martinez-Moreno, J.M.; Herencia, C.; Montes de Oca, A.; Munoz-Castaneda, J.R.; Rodriguez-Ortiz, M.E.; Diaz-Tocados, J.M.; Peralbo-Santaella, E.; Camargo, A.; Canalejo, A.; Rodriguez, M.; et al. Vitamin D modulates tissue factor and protease-activated receptor 2 expression in vascular smooth muscle cells. FASEB J. 2016, 30, 1367-1376. [CrossRef] [PubMed]

163. Wu-Wong, J.R.; Nakane, M.; Ma, J. Vitamin D analogs modulate the expression of plasminogen activator inhibitor-1, thrombospondin-1 and thrombomodulin in human aortic smooth muscle cells. J. Vasc. Res. 2007, 44, 11-18. [CrossRef] [PubMed]

164. Molinari, C.; Uberti, F.; Grossini, E.; Vacca, G.; Carda, S.; Invernizzi, M.; Cisari, C. 1- $\alpha-25$-Dihydroxycholecalciferol induces nitric oxide production in cultured endothelial cells. Cell. Physiol. Biochem. 2011, 27, 661-668. [CrossRef] [PubMed]

165. Bozic, M.; Alvarez, A.; de Pablo, C.; Sanchez-Nino, M.D.; Ortiz, A.; Dolcet, X.; Encinas, M.; Fernandez, E.; Valdivielso, J.M. Impaired Vitamin D Signaling in Endothelial Cell Leads to an Enhanced Leukocyte-Endothelium Interplay: Implications for Atherosclerosis Development. PLoS ONE 2015, 10, e0136863. [CrossRef] [PubMed]

166. Oh, J.; Weng, S.; Felton, S.K.; Bhandare, S.; Riek, A.; Butler, B.; Proctor, B.M.; Petty, M.; Chen, Z.; Schechtman, K.B.; et al. 1,25(OH)2 vitamin D inhibits foam cell formation and suppresses macrophage cholesterol uptake in patients with type 2 diabetes mellitus. Circulation 2009, 120, 687-698. [CrossRef] [PubMed] 
167. Norman, P.E.; Powell, J.T. Vitamin D and cardiovascular disease. Circ. Res. 2014, 114, 379-393. [CrossRef] [PubMed]

168. Pilz, S.; Verheyen, N.; Grubler, M.R.; Tomaschitz, A.; Marz, W. Vitamin D and cardiovascular disease prevention. Nat. Rev. Cardiol. 2016, 13, 404-417. [CrossRef] [PubMed]

169. Xiang, W.; Kong, J.; Chen, S.; Cao, L.P.; Qiao, G.; Zheng, W.; Liu, W.; Li, X.; Gardner, D.G.; Li, Y.C. Cardiac hypertrophy in vitamin D receptor knockout mice: Role of the systemic and cardiac renin-angiotensin systems. Am. J. Physiol. Endocrinol. Metab. 2005, 288, E125-E132. [CrossRef] [PubMed]

170. Zhou, C.; Lu, F.; Cao, K.; Xu, D.; Goltzman, D.; Miao, D. Calcium-independent and 1,25(OH)2D3-dependent regulation of the renin-angiotensin system in 1- $\alpha$-hydroxylase knockout mice. Kidney Int. 2008, 74, 170-179. [CrossRef] [PubMed]

171. Chen, S.; Law, C.S.; Grigsby, C.L.; Olsen, K.; Hong, T.T.; Zhang, Y.; Yeghiazarians, Y.; Gardner, D.G. Cardiomyocyte-specific deletion of the vitamin D receptor gene results in cardiac hypertrophy. Circulation 2011, 124, 1838-1847. [CrossRef] [PubMed]

172. Kong, J.; Kim, G.H.; Wei, M.; Sun, T.; Li, G.; Liu, S.Q.; Li, X.; Bhan, I.; Zhao, Q.; Thadhani, R.; et al. Therapeutic effects of vitamin $\mathrm{D}$ analogs on cardiac hypertrophy in spontaneously hypertensive rats. Am. J. Pathol. 2010, 177, 622-631. [CrossRef] [PubMed]

173. O'Connell, T.D.; Simpson, R.U. 1,25-Dihydroxyvitamin D3 regulation of myocardial growth and c-myc levels in the rat heart. Biochem. Biophys. Res. Commun. 1995, 213, 59-65. [CrossRef] [PubMed]

174. Al-Khalidi, B.; Kimball, S.M.; Rotondi, M.A.; Ardern, C.I. Standardized serum 25-hydroxyvitamin D concentrations are inversely associated with cardiometabolic disease in U.S. adults: A cross-sectional analysis of NHANES, 2001-2010. Nutr. J. 2017, 16, 16. [CrossRef] [PubMed]

175. Campos, R.M.; Masquio, D.C.; Corgosinho, F.C.; Carvalho-Ferreira, J.P.; Netto, B.D.; Ackel-D’Elia, C.; Tock, L.; Tufik, S.; de Mello, M.T.; Damaso, A.R. Low vitamin D intake is associated with increase in cardiovascular risk factors in obese adolescents. Endocr. Regul. 2015, 49, 11-19. [CrossRef] [PubMed]

176. Chen, W.R.; Qian, Y.A.; Chen, Y.D.; Shi, Y.; Yin, D.W.; Wang, H.; Zhu, P.; Liu, H.W.; Sha, Y. The effects of low vitamin D on coronary artery disease. Heart Lung Circ. 2014, 23, 314-319. [CrossRef] [PubMed]

177. Liu, L.C.; Voors, A.A.; van Veldhuisen, D.J.; van der Veer, E.; Belonje, A.M.; Szymanski, M.K.; Sillje, H.H.; van Gilst, W.H.; Jaarsma, T.; de Boer, R.A. Vitamin D status and outcomes in heart failure patients. Eur. J. Heart Fail. 2011, 13, 619-625. [CrossRef] [PubMed]

178. Wu, Z.; Wang, T.; Zhu, S.; Li, L. Effects of vitamin D supplementation as an adjuvant therapy in coronary artery disease patients. Scand. Cardiovasc. J. 2016, 50, 9-16. [CrossRef] [PubMed]

179. Boxer, R.S.; Hoit, B.D.; Schmotzer, B.J.; Stefano, G.T.; Gomes, A.; Negrea, L. The effect of vitamin D on aldosterone and health status in patients with heart failure. J. Card. Fail. 2014, 20, 334-342. [CrossRef] [PubMed]

180. Shedeed, S.A. Vitamin D supplementation in infants with chronic congestive heart failure. Pediatr. Cardiol. 2012, 33, 713-719. [CrossRef] [PubMed]

181. Zhang, R.; Li, B.; Gao, X.; Tian, R.; Pan, Y.; Jiang, Y.; Gu, H.; Wang, Y.; Wang, Y.; Liu, G. Serum 25-hydroxyvitamin $\mathrm{D}$ and the risk of cardiovascular disease: Dose-response meta-analysis of prospective studies. Am. J. Clin. Nutr. 2017, 105, 810-819. [CrossRef] [PubMed]

182. Ramly, M.; Ming, M.F.; Chinna, K.; Suboh, S.; Pendek, R. Effect of vitamin D supplementation on cardiometabolic risks and health-related quality of life among urban premenopausal women in a tropical country-A randomized controlled trial. PLOS ONE 2014, 9, e110476. [CrossRef] [PubMed]

183. Sokol, S.I.; Srinivas, V.; Crandall, J.P.; Kim, M.; Tellides, G.; Lebastchi, A.H.; Yu, Y.; Gupta, A.K.; Alderman, M.H. The effects of vitamin D repletion on endothelial function and inflammation in patients with coronary artery disease. Vasc. Med. 2012, 17, 394-404. [CrossRef] [PubMed]

184. Witham, M.D.; Dove, F.J.; Khan, F.; Lang, C.C.; Belch, J.J.; Struthers, A.D. Effects of vitamin D supplementation on markers of vascular function after myocardial infarction-A randomised controlled trial. Int. J. Cardiol. 2013, 167, 745-749. [CrossRef] [PubMed]

185. Manson, J.E.; Allison, M.A.; Carr, J.J.; Langer, R.D.; Cochrane, B.B.; Hendrix, S.L.; Hsia, J.; Hunt, J.R.; Lewis, C.E.; Margolis, K.L.; et al. Calcium/vitamin D supplementation and coronary artery calcification in the Women's Health Initiative. Menopause 2010, 17, 683-691. [CrossRef] [PubMed] 
186. Palmer, M.T.; Lee, Y.K.; Maynard, C.L.; Oliver, J.R.; Bikle, D.D.; Jetten, A.M.; Weaver, C.T. Lineage-specific effects of 1,25-dihydroxyvitamin D3 on the development of effector CD4 T cells. J. Biol. Chem. 2011, 286, 997-1004. [CrossRef] [PubMed]

187. Grau-Lopez, L.; Granada, M.L.; Raich-Regue, D.; Naranjo-Gomez, M.; Borras-Serres, F.E.; Martinez-Caceres, E.; Ramo-Tello, C. Regulatory role of vitamin D in T-cell reactivity against myelin peptides in relapsing-remitting multiple sclerosis patients. BMC Neurol. 2012, 12, 103. [CrossRef] [PubMed]

188. Ramagopalan, S.V.; Maugeri, N.J.; Handunnetthi, L.; Lincoln, M.R.; Orton, S.M.; Dyment, D.A.; Deluca, G.C.; Herrera, B.M.; Chao, M.J.; Sadovnick, A.D.; et al. Expression of the multiple sclerosis-associated MHC class II Allele HLA-DRB1*1501 is regulated by vitamin D. PLoS Genet. 2009, 5, e1000369. [CrossRef] [PubMed]

189. Rhead, B.; Baarnhielm, M.; Gianfrancesco, M.; Mok, A.; Shao, X.; Quach, H.; Shen, L.; Schaefer, C.; Link, J.; Gyllenberg, A.; et al. Mendelian randomization shows a causal effect of low vitamin D on multiple sclerosis risk. Neurol. Genet. 2016, 2, e97. [CrossRef] [PubMed]

190. Munger, K.L.; Zhang, S.M.; O’Reilly, E.; Hernan, M.A.; Olek, M.J.; Willett, W.C.; Ascherio, A. Vitamin D intake and incidence of multiple sclerosis. Neurology 2004, 62, 60-65. [CrossRef] [PubMed]

191. Ashtari, F.; Toghianifar, N.; Zarkesh-Esfahani, S.H.; Mansourian, M. High dose Vitamin D intake and quality of life in relapsing-remitting multiple sclerosis: A randomized, double-blind, placebo-controlled clinical trial. Neurol. Res. 2016, 38, 888-892. [CrossRef] [PubMed]

192. Achiron, A.; Givon, U.; Magalashvili, D.; Dolev, M.; Liraz Zaltzman, S.; Kalron, A.; Stern, Y.; Mazor, Z.; Ladkani, D.; Barak, Y. Effect of Alfacalcidol on multiple sclerosis-related fatigue: A randomized, double-blind placebo-controlled study. Mult. Scler. 2015, 21, 767-775. [CrossRef] [PubMed]

193. Soilu-Hanninen, M.; Aivo, J.; Lindstrom, B.M.; Elovaara, I.; Sumelahti, M.L.; Farkkila, M.; Tienari, P.; Atula, S.; Sarasoja, T.; Herrala, L.; et al. A randomised, double blind, placebo controlled trial with vitamin D3 as an add on treatment to interferon $\beta-1 \mathrm{~b}$ in patients with multiple sclerosis. J. Neurol. Neurosurg. Psychiatry 2012, 83, 565-571. [CrossRef] [PubMed]

194. Najafipoor, A.; Roghanian, R.; Zarkesh-Esfahani, S.H.; Bouzari, M.; Etemadifar, M. The beneficial effects of vitamin D3 on reducing antibody titers against Epstein-Barr virus in multiple sclerosis patients. Cell. Immunol. 2015, 294, 9-12. [CrossRef] [PubMed]

195. Kampman, M.T.; Steffensen, L.H.; Mellgren, S.I.; Jorgensen, L. Effect of vitamin D3 supplementation on relapses, disease progression, and measures of function in persons with multiple sclerosis: Exploratory outcomes from a double-blind randomised controlled trial. Mult. Scler. 2012, 18, 1144-1151. [CrossRef] [PubMed]

196. Mosayebi, G.; Ghazavi, A.; Ghasami, K.; Jand, Y.; Kokhaei, P. Therapeutic effect of vitamin D3 in multiple sclerosis patients. Immunol. Investig. 2011, 40, 627-639. [CrossRef] [PubMed]

197. Shahin, D.; El-Farahaty, R.M.; Houssen, M.E.; Machaly, S.A.; Sallam, M.; ElSaid, T.O.; Neseem, N.O. Serum 25-OH vitamin D level in treatment-naive systemic lupus erythematosus patients: Relation to disease activity, IL-23 and IL-17. Lupus 2017, 26, 917-926. [CrossRef] [PubMed]

198. Gao, C.C.; Liu, S.Y.; Wu, Z.Z.; Li, T.F.; Gao, G.M.; Liu, Z.S.; Zheng, Z.H. Severe vitamin D deficiency increases the risk for moderate to severe disease activity in Chinese patients with SLE. Lupus 2016, 25, 1224-1229. [CrossRef] [PubMed]

199. Lima, G.L.; Paupitz, J.; Aikawa, N.E.; Takayama, L.; Bonfa, E.; Pereira, R.M. Vitamin D Supplementation in Adolescents and Young Adults With Juvenile Systemic Lupus Erythematosus for Improvement in Disease Activity and Fatigue Scores: A Randomized, Double-Blind, Placebo-Controlled Trial. Arthritis Care Res. 2016, 68, 91-98. [CrossRef] [PubMed]

200. Abou-Raya, A.; Abou-Raya, S.; Helmii, M. The effect of vitamin D supplementation on inflammatory and hemostatic markers and disease activity in patients with systemic lupus erythematosus: A randomized placebo-controlled trial. J. Rheumatol. 2013, 40, 265-272. [CrossRef] [PubMed]

201. Terrier, B.; Derian, N.; Schoindre, Y.; Chaara, W.; Geri, G.; Zahr, N.; Mariampillai, K.; Rosenzwajg, M.; Carpentier, W.; Musset, L.; et al. Restoration of regulatory and effector T cell balance and B cell homeostasis in systemic lupus erythematosus patients through vitamin D supplementation. Arthritis Res. Ther. 2012, 14, R221. [CrossRef] [PubMed]

202. Jeffery, L.E.; Raza, K.; Hewison, M. Vitamin D in rheumatoid arthritis-towards clinical application. Nat. Rev. Rheumatol. 2016, 12, 201-210. [CrossRef] [PubMed] 
203. Feng, X.; Lv, C.; Wang, F.; Gan, K.; Zhang, M.; Tan, W. Modulatory effect of 1,25-dihydroxyvitamin D 3 on IL1 $\beta$-induced RANKL, OPG, TNF $\alpha$, and IL-6 expression in human rheumatoid synoviocyte MH7A. Clin. Dev. Immunol. 2013, 2013, 1-8. [CrossRef] [PubMed]

204. Baker, J.F.; Baker, D.G.; Toedter, G.; Shults, J.; Von Feldt, J.M.; Leonard, M.B. Associations between vitamin $\mathrm{D}$, disease activity, and clinical response to therapy in rheumatoid arthritis. Clin. Exp. Rheumatol. 2012, 30, 658-664. [PubMed]

205. Welsh, P.; Peters, M.J.; McInnes, I.B.; Lems, W.F.; Lips, P.T.; McKellar, G.; Knox, S.; Michael Wallace, A.; Dijkmans, B.A.; Nurmohamed, M.T.; et al. Vitamin D deficiency is common in patients with RA and linked to disease activity, but circulating levels are unaffected by TNF $\alpha$ blockade: Results from a prospective cohort study. Ann. Rheum. Dis. 2011, 70, 1165-1167. [CrossRef] [PubMed]

206. Gopinath, K.; Danda, D. Supplementation of 1,25 dihydroxy vitamin D3 in patients with treatment naive early rheumatoid arthritis: A randomised controlled trial. Int. J. Rheum. Dis. 2011, 14, 332-339. [CrossRef] [PubMed]

207. Andjelkovic, Z.; Vojinovic, J.; Pejnovic, N.; Popovic, M.; Dujic, A.; Mitrovic, D.; Pavlica, L.; Stefanovic, D. Disease modifying and immunomodulatory effects of high dose $1-\alpha-(\mathrm{OH}) \mathrm{D} 3$ in rheumatoid arthritis patients. Clin. Exp. Rheumatol. 1999, 17, 453-456. [PubMed]

208. Hansen, K.E.; Bartels, C.M.; Gangnon, R.E.; Jones, A.N.; Gogineni, J. An evaluation of high-dose vitamin D for rheumatoid arthritis. J. Clin. Rheumatol. 2014, 20, 112-114. [CrossRef] [PubMed]

209. Chen, W.; Lin, H.; Wang, M. Immune intervention effects on the induction of experimental autoimmune thyroiditis. J. Huazhong Univ. Sci. Technol. Med. Sci. 2002, 22, 343-345. [CrossRef] [PubMed]

210. Liu, S.; Xiong, F.; Liu, E.M.; Zhu, M.; Lei, P.Y. Effects of 1,25-dihydroxyvitamin D3 in rats with experimental autoimmune thyroiditis. Nan Fang Yi Ke Da Xue Xue Bao 2010, 30, 1573-1576. [PubMed]

211. Muscogiuri, G.; Mari, D.; Prolo, S.; Fatti, L.M.; Cantone, M.C.; Garagnani, P.; Arosio, B.; Di Somma, C.; Vitale, G. 25 Hydroxyvitamin D Deficiency and Its Relationship to Autoimmune Thyroid Disease in the Elderly. Int. J. Environ. Res. Public Health 2016, 13, 850. [CrossRef] [PubMed]

212. Ma, J.; Wu, D.; Li, C.; Fan, C.; Chao, N.; Liu, J.; Li, Y.; Wang, R.; Miao, W.; Guan, H.; et al. Lower Serum 25-Hydroxyvitamin D Level is Associated With 3 Types of Autoimmune Thyroid Diseases. Medicine 2015, 94, e1639. [CrossRef] [PubMed]

213. Wang, J.; Lv, S.; Chen, G.; Gao, C.; He, J.; Zhong, H.; Xu, Y. Meta-analysis of the association between vitamin D and autoimmune thyroid disease. Nutrients 2015, 7, 2485-2498. [CrossRef] [PubMed]

214. Kivity, S.; Agmon-Levin, N.; Zisappl, M.; Shapira, Y.; Nagy, E.V.; Danko, K.; Szekanecz, Z.; Langevitz, P.; Shoenfeld, Y. Vitamin D and autoimmune thyroid diseases. Cell. Mol. Immunol. 2011, 8, 243-247. [CrossRef] [PubMed]

215. Wang, X.; Zynat, J.; Guo, Y.; Osiman, R.; Tuhuti, A.; Zhao, H.; Abdunaimu, M.; Wang, H.; Jin, X.; Xing, S. Low Serum Vitamin D Is Associated with Anti-Thyroid-Globulin Antibody in Female Individuals. Int. J. Endocrinol. 2015, 2015, 1-6. [CrossRef] [PubMed]

216. Yasmeh, J.; Farpour, F.; Rizzo, V.; Kheradnam, S.; Sachmechi, I. Hashimoto Thyroiditis Not Associated with Vitamin D Deficiency. Endocr. Pract. 2016, 22, 809-813. [CrossRef] [PubMed]

217. D'Aurizio, F.; Villalta, D.; Metus, P.; Doretto, P.; Tozzoli, R. Is vitamin D a player or not in the pathophysiology of autoimmune thyroid diseases? Autoimmun. Rev. 2015, 14, 363-369. [CrossRef] [PubMed]

218. Effraimidis, G.; Badenhoop, K.; Tijssen, J.G.; Wiersinga, W.M. Vitamin D deficiency is not associated with early stages of thyroid autoimmunity. Eur. J. Endocrinol. 2012, 167, 43-48. [CrossRef] [PubMed]

219. Simsek, Y.; Cakir, I.; Yetmis, M.; Dizdar, O.S.; Baspinar, O.; Gokay, F. Effects of Vitamin D treatment on thyroid autoimmunity. J. Res. Med. Sci. 2016, 21, 85. [PubMed]

220. Alhuzaim, O.N.; Aljohani, N. Effect of vitamin D3 on untreated graves' disease with vitamin D deficiency. Clin. Med. Insights Case Rep. 2014, 7, 83-85. [CrossRef] [PubMed]

221. Vahabi Anaraki, P.; Aminorroaya, A.; Amini, M.; Momeni, F.; Feizi, A.; Iraj, B.; Tabatabaei, A. Effect of Vitamin D deficiency treatment on thyroid function and autoimmunity markers in Hashimoto's thyroiditis: A double-blind randomized placebo-controlled clinical trial. J. Res. Med. Sci. 2017, 22, 103. [PubMed]

222. Zerr, P.; Vollath, S.; Palumbo-Zerr, K.; Tomcik, M.; Huang, J.; Distler, A.; Beyer, C.; Dees, C.; Gela, K.; Distler, O.; et al. Vitamin D receptor regulates TGF- $\beta$ signalling in systemic sclerosis. Ann. Rheum. Dis. 2015, 74, e20. [CrossRef] [PubMed] 
223. Vacca, A.; Cormier, C.; Mathieu, A.; Kahan, A.; Allanore, Y. Vitamin D levels and potential impact in systemic sclerosis. Clin. Exp. Rheumatol. 2011, 29, 1024-1031. [PubMed]

224. Giuggioli, D.; Colaci, M.; Cassone, G.; Fallahi, P.; Lumetti, F.; Spinella, A.; Campomori, F.; Manfredi, A.; Manzini, C.U.; Antonelli, A.; et al. Serum 25-OH vitamin D levels in systemic sclerosis: Analysis of 140 patients and review of the literature. Clin. Rheumatol. 2017, 36, 583-590. [CrossRef] [PubMed]

225. Rios Fernandez, R.; Fernandez Roldan, C.; Callejas Rubio, J.L.; Ortego Centeno, N. Vitamin D deficiency in a cohort of patients with systemic scleroderma from the south of Spain. J. Rheumatol. 2010, 37, 1355. [CrossRef] [PubMed]

226. Gambichler, T.; Chrobok, I.; Hoxtermann, S.; Kreuter, A. Significantly decreased serum 25-hydroxyvitamin D levels in a large german systemic sclerosis cohort. J. Rheumatol. 2011, 38, 2492-2493. [CrossRef] [PubMed]

227. Atteritano, M.; Santoro, D.; Corallo, G.; Visalli, E.; Buemi, M.; Catalano, A.; Lasco, A.; Bitto, A.; Squadrito, F. Skin Involvement and Pulmonary Hypertension Are Associated with Vitamin D Insufficiency in Scleroderma. Int. J. Mol. Sci. 2016, 17, 2103. [CrossRef] [PubMed]

228. Zhang, L.; Duan, Y.; Zhang, T.P.; Huang, X.L.; Li, B.Z.; Ye, D.Q.; Wang, J. Association between the serum level of vitamin D and systemic sclerosis in a Chinese population: A case control study. Int. J. Rheum. Dis. 2017, 20, 1002-1008. [CrossRef] [PubMed]

229. An, L.; Sun, M.H.; Chen, F.; Li, J.R. Vitamin D levels in systemic sclerosis patients: A meta-analysis. Drug Des. Dev. Ther. 2017, 11, 3119-3125. [CrossRef] [PubMed]

230. Trombetta, A.C.; Smith, V.; Gotelli, E.; Ghio, M.; Paolino, S.; Pizzorni, C.; Vanhaecke, A.; Ruaro, B.; Sulli, A.; Cutolo, M. Vitamin D deficiency and clinical correlations in systemic sclerosis patients: A retrospective analysis for possible future developments. PLOS ONE 2017, 12, e0179062. [CrossRef] [PubMed]

231. Groseanu, L.; Bojinca, V.; Gudu, T.; Saulescu, I.; Predeteanu, D.; Balanescu, A.; Berghea, F.; Opris, D.; Borangiu, A.; Constantinescu, C.; et al. Low vitamin D status in systemic sclerosis and the impact on disease phenotype. Eur. J. Rheumatol. 2016, 3, 50-55. [CrossRef] [PubMed]

232. Atteritano, M.; Sorbara, S.; Bagnato, G.; Miceli, G.; Sangari, D.; Morgante, S.; Visalli, E. Bone mineral density, bone turnover markers and fractures in patients with systemic sclerosis: A case control study. PLoS ONE 2013, 8, e66991. [CrossRef] [PubMed]

233. Matsuoka, L.Y.; Dannenberg, M.J.; Wortsman, J.; Hollis, B.W.; Jimenez, S.A.; Varga, J. Cutaneous vitamin D3 formation in progressive systemic sclerosis. J. Rheumatol. 1991, 18, 1196-1198. [PubMed]

234. Humbert, P.; Dupond, J.L.; Agache, P.; Laurent, R.; Rochefort, A.; Drobacheff, C.; de Wazieres, B.; Aubin, F. Treatment of scleroderma with oral 1,25-dihydroxyvitamin D3: Evaluation of skin involvement using non-invasive techniques. Results of an open prospective trial. Acta Derm. Venereol. 1993, 73, 449-451. [PubMed]

235. Hulshof, M.M.; Bouwes Bavinck, J.N.; Bergman, W.; Masclee, A.A.; Heickendorff, L.; Breedveld, F.C.; Dijkmans, B.A. Double-blind, placebo-controlled study of oral calcitriol for the treatment of localized and systemic scleroderma. J. Am. Acad. Dermatol. 2000, 43, 1017-1023. [CrossRef] [PubMed]

236. Di Filippo, P.; Scaparrotta, A.; Rapino, D.; Cingolani, A.; Attanasi, M.; Petrosino, M.I.; Chuang, K.; Di Pillo, S.; Chiarelli, F. Vitamin D supplementation modulates the immune system and improves atopic dermatitis in children. Int. Arch. Allergy Immunol. 2015, 166, 91-96. [CrossRef] [PubMed]

237. Hartmann, B.; Riedel, R.; Jorss, K.; Loddenkemper, C.; Steinmeyer, A.; Zugel, U.; Babina, M.; Radbruch, A.; Worm, M. Vitamin D receptor activation improves allergen-triggered eczema in mice. J. Investig. Dermatol. 2012, 132, 330-336. [CrossRef] [PubMed]

238. Yip, K.H.; Kolesnikoff, N.; Yu, C.; Hauschild, N.; Taing, H.; Biggs, L.; Goltzman, D.; Gregory, P.A.; Anderson, P.H.; Samuel, M.S.; et al. Mechanisms of vitamin D3 metabolite repression of IgE-dependent mast cell activation. J. Allergy Clin. Immunol. 2014, 133, 1356-1364. [CrossRef] [PubMed]

239. Yang, A.R.; Kim, Y.N.; Lee, B.H. Dietary intakes and lifestyle patterns of Korean children and adolescents with atopic dermatitis: Using the fourth and fifth Korean National Health and Nutrition Examination Survey (KNHANES IV,V), 2007-11. Ecol. Food Nutr. 2016, 55, 50-64. [CrossRef] [PubMed]

240. El Taieb, M.A.; Fayed, H.M.; Aly, S.S.; Ibrahim, A.K. Assessment of serum 25-hydroxyvitamin D levels in children with atopic dermatitis: Correlation with SCORAD index. Dermatitis 2013, 24, 296-301. [CrossRef] [PubMed] 
241. Peroni, D.G.; Piacentini, G.L.; Cametti, E.; Chinellato, I.; Boner, A.L. Correlation between serum 25-hydroxyvitamin D levels and severity of atopic dermatitis in children. Br. J. Dermatol. 2011, 164, 1078-1082. [CrossRef] [PubMed]

242. Cheng, H.M.; Kim, S.; Park, G.H.; Chang, S.E.; Bang, S.; Won, C.H.; Lee, M.W.; Choi, J.H.; Moon, K.C. Low vitamin D levels are associated with atopic dermatitis, but not allergic rhinitis, asthma, or IgE sensitization, in the adult Korean population. J. Allergy Clin. Immunol. 2014, 133, 1048-1055. [CrossRef] [PubMed]

243. Camargo, C.A., Jr.; Ganmaa, D.; Sidbury, R.; Erdenedelger, K.; Radnaakhand, N.; Khandsuren, B. Randomized trial of vitamin D supplementation for winter-related atopic dermatitis in children. J. Allergy Clin. Immunol. 2014, 134, 831-835. [CrossRef] [PubMed]

244. Amestejani, M.; Salehi, B.S.; Vasigh, M.; Sobhkhiz, A.; Karami, M.; Alinia, H.; Kamrava, S.K.; Shamspour, N.; Ghalehbaghi, B.; Behzadi, A.H. Vitamin D supplementation in the treatment of atopic dermatitis: A clinical trial study. J. Drugs Dermatol. 2012, 11, 327-330. [PubMed]

245. Javanbakht, M.H.; Keshavarz, S.A.; Djalali, M.; Siassi, F.; Eshraghian, M.R.; Firooz, A.; Seirafi, H.; Ehsani, A.H.; Chamari, M.; Mirshafiey, A. Randomized controlled trial using vitamins E and D supplementation in atopic dermatitis. J. Dermatol. Treat. 2011, 22, 144-150. [CrossRef] [PubMed]

246. Karthaus, N.; van Spriel, A.B.; Looman, M.W.; Chen, S.; Spilgies, L.M.; Lieben, L.; Carmeliet, G.; Ansems, M.; Adema, G.J. Vitamin D controls murine and human plasmacytoid dendritic cell function. J. Investig. Dermatol. 2014, 134, 1255-1264. [CrossRef] [PubMed]

247. Dyring-Andersen, B.; Bonefeld, C.M.; Bzorek, M.; Lovendorf, M.B.; Lauritsen, J.P.; Skov, L.; Geisler, C. The Vitamin D Analogue Calcipotriol Reduces the Frequency of CD8 ${ }^{+} \mathrm{IL}_{-1} 7^{+} \mathrm{T}$ Cells in Psoriasis Lesions. Scand. J. Immunol. 2015, 82, 84-91. [CrossRef] [PubMed]

248. Hoss, E.; Austin, H.R.; Batie, S.F.; Jurutka, P.W.; Haussler, M.R.; Whitfield, G.K. Control of late cornified envelope genes relevant to psoriasis risk: Upregulation by 1,25-dihydroxyvitamin D3 and plant-derived delphinidin. Arch. Dermatol. Res. 2013, 305, 867-878. [CrossRef] [PubMed]

249. Maleki, M.; Nahidi, Y.; Azizahari, S.; Meibodi, N.T.; Hadianfar, A. Serum 25-OH Vitamin D Level in Psoriatic Patients and Comparison with Control Subjects. J. Cutan. Med. Surg. 2016, 20, 207-210. [CrossRef] [PubMed]

250. Gisondi, P.; Rossini, M.; Di Cesare, A.; Idolazzi, L.; Farina, S.; Beltrami, G.; Peris, K.; Girolomoni, G. Vitamin D status in patients with chronic plaque psoriasis. Br. J. Dermatol. 2012, 166, 505-510. [CrossRef] [PubMed]

251. Lebwohl, M.; Menter, A.; Weiss, J.; Clark, S.D.; Flores, J.; Powers, J.; Balin, A.K.; Kempers, S.; Glinert, R.J.; Fleming, T.; et al. Calcitriol $3 \mathrm{microg} / \mathrm{g}$ ointment in the management of mild to moderate plaque type psoriasis: Results from 2 placebo-controlled, multicenter, randomized double-blind, clinical studies. J. Drugs Dermatol. 2007, 6, 428-435. [PubMed]

252. Durakovic, C.; Ray, S.; Holick, M.F. Topical paricalcitol (19-nor-1- $\alpha$-25-dihydroxyvitamin D2) is a novel, safe and effective treatment for plaque psoriasis: A pilot study. Br. J. Dermatol. 2004, 151, 190-195. [CrossRef] [PubMed]

253. Helfrich, Y.R.; Kang, S.; Hamilton, T.A.; Voorhees, J.J. Topical becocalcidiol for the treatment of psoriasis vulgaris: A randomized, placebo-controlled, double-blind, multicentre study. Br. J. Dermatol. 2007, 157, 369-374. [CrossRef] [PubMed]

254. Barker, J.N.; Ashton, R.E.; Marks, R.; Harris, R.I.; Berth-Jones, J. Topical maxacalcitol for the treatment of psoriasis vulgaris: A placebo-controlled, double-blind, dose-finding study with active comparator. Br. J. Dermatol. 1999, 141, 274-278. [CrossRef] [PubMed]

255. Umezawa, Y.; Nakagawa, H.; Tamaki, K. Phase III clinical study of maxacalcitol ointment in patients with palmoplantar pustulosis: A randomized, double-blind, placebo-controlled trial. J. Dermatol. 2016, 43, 288-293. [CrossRef] [PubMed]

256. Choi, J.W.; Choi, J.W.; Kwon, I.H.; Youn, J.I. High-concentration $\left(20 \mu \mathrm{g}^{-\mathrm{g}^{-1}}\right)$ tacalcitol ointment in the treatment of facial psoriasis: An 8-week open-label clinical trial. Br. J. Dermatol. 2010, 162, 1359-1364. [CrossRef] [PubMed]

257. Duweb, G.; Alhaddar, J.; Abuhamida, M. Calcipotriol solution in scalp psoriasis. Int. J. Tissue React. 2005, 27, 163-166. [PubMed]

258. Zakeri, M.; Valikhani, M.; Mortazavi, H.; Barzegari, M. Topical calcipotriol therapy in nail psoriasis: A study of 24 cases. Dermatol. Online J. 2005, 11, 5. [PubMed] 
259. AlGhamdi, K.; Kumar, A.; Moussa, N. The role of vitamin D in melanogenesis with an emphasis on vitiligo. Indian J. Dermatol. Venereol. Leprol. 2013, 79, 750-758. [CrossRef] [PubMed]

260. Li, Q.L.; Wu, Y.H.; Niu, M.; Lu, X.J.; Huang, Y.H.; He, D.H. Protective effects of tacalcitol against oxidative damage in human epidermal melanocytes. Int. J. Dermatol. 2017, 56, 232-238. [CrossRef] [PubMed]

261. Khurrum, H.; AlGhamdi, K.M. The Relationship between the Serum Level of Vitamin D and Vitiligo: A Controlled Study on 300 Subjects. J. Cutan. Med. Surg. 2016, 20, 139-145. [CrossRef] [PubMed]

262. Beheshti, A.; Ghadami, H.; Barikani, A.; Haj Manouchehri, F. Assessment of vitamin D plasma levels in patients with vitiligo vulgaris. Acta Med. Iran. 2014, 52, 601-606. [PubMed]

263. Ustun, I.; Seraslan, G.; Gokce, C.; Motor, S.; Can, Y.; Ugur Inan, M.; Yilmaz, N. Investigation of vitamin D levels in patients with vitiligo vulgaris. Acta Dermatovenerol. Croat. 2014, 22, 110-113. [PubMed]

264. Parsad, D.; Saini, R.; Nagpal, R. Calcipotriol in vitiligo: A preliminary study. Pediatr. Dermatol. 1999, 16, 317-320. [CrossRef] [PubMed]

265. Ameen, M.; Exarchou, V.; Chu, A.C. Topical calcipotriol as monotherapy and in combination with psoralen plus ultraviolet A in the treatment of vitiligo. Br. J. Dermatol. 2001, 145, 476-479. [CrossRef] [PubMed]

266. Lu-yan, T.; Wen-wen, F.; Lei-hong, X.; Yi, J.; Zhi-zhong, Z. Topical tacalcitol and 308-nm monochromatic excimer light: A synergistic combination for the treatment of vitiligo. Photodermatol. Photoimmunol. Photomed. 2006, 22, 310-314. [CrossRef] [PubMed]

267. Chiaverini, C.; Passeron, T.; Ortonne, J.P. Treatment of vitiligo by topical calcipotriol. J. Eur. Acad. Dermatol. Venereol. 2002, 16, 137-138. [CrossRef] [PubMed]

268. Rodriguez-Martin, M.; Garcia Bustinduy, M.; Saez Rodriguez, M.; Noda Cabrera, A. Randomized, double-blind clinical trial to evaluate the efficacy of topical tacalcitol and sunlight exposure in the treatment of adult nonsegmental vitiligo. Br. J. Dermatol. 2009, 160, 409-414. [CrossRef] [PubMed]

269. Wat, H.; Dytoc, M. Off-label uses of topical vitamin D in dermatology: A systematic review. J. Cutan. Med. Surg. 2014, 18, 91-108. [CrossRef] [PubMed]

270. Thomson, R.L.; Spedding, S.; Buckley, J.D. Vitamin D in the aetiology and management of polycystic ovary syndrome. Clin. Endocrinol. 2012, 77, 343-350. [CrossRef] [PubMed]

271. Li, H.W.; Brereton, R.E.; Anderson, R.A.; Wallace, A.M.; Ho, C.K. Vitamin D deficiency is common and associated with metabolic risk factors in patients with polycystic ovary syndrome. Metabolism 2011, 60, 1475-1481. [CrossRef] [PubMed]

272. Jia, X.Z.; Wang, Y.M.; Zhang, N.; Guo, L.N.; Zhen, X.L.; Li, H.; Wei, L. Effect of vitamin D on clinical and biochemical parameters in polycystic ovary syndrome women: A meta-analysis. J. Obstet. Gynaecol. Res. 2015, 41, 1791-1802. [CrossRef] [PubMed]

273. Fang, F.; Ni, K.; Cai, Y.; Shang, J.; Zhang, X.; Xiong, C. Effect of vitamin D supplementation on polycystic ovary syndrome: A systematic review and meta-analysis of randomized controlled trials. Complement. Ther. Clin. Pract. 2017, 26, 53-60. [CrossRef] [PubMed]

274. Xue, Y.; Xu, P.; Xue, K.; Duan, X.; Cao, J.; Luan, T.; Li, Q.; Gu, L. Effect of vitamin D on biochemical parameters in polycystic ovary syndrome women: A meta-analysis. Arch. Gynecol. Obstet. 2017, 295, 487-496. [CrossRef] [PubMed]

275. Foroozanfard, F.; Jamilian, M.; Bahmani, F.; Talaee, R.; Talaee, N.; Hashemi, T.; Nasri, K.; Asemi, Z.; Esmaillzadeh, A. Calcium plus vitamin D supplementation influences biomarkers of inflammation and oxidative stress in overweight and vitamin D-deficient women with polycystic ovary syndrome: A randomized double-blind placebo-controlled clinical trial. Clin. Endocrinol. 2015, 83, 888-894. [CrossRef] [PubMed]

276. Irani, M.; Seifer, D.B.; Grazi, R.V.; Irani, S.; Rosenwaks, Z.; Tal, R. Vitamin D Decreases Serum VEGF Correlating with Clinical Improvement in Vitamin D-Deficient Women with PCOS: A Randomized Placebo-Controlled Trial. Nutrients 2017, 9, 334. [CrossRef] [PubMed]

277. Irani, M.; Seifer, D.B.; Grazi, R.V.; Julka, N.; Bhatt, D.; Kalgi, B.; Irani, S.; Tal, O.; Lambert-Messerlian, G.; Tal, R. Vitamin D Supplementation Decreases TGF- $\beta 1$ Bioavailability in PCOS: A Randomized Placebo-Controlled Trial. J. Clin. Endocrinol. Metab. 2015, 100, 4307-4314. [CrossRef] [PubMed] 
278. Figurova, J.; Dravecka, I.; Petrikova, J.; Javorsky, M.; Lazurova, I. The effect of alfacalcidiol and metformin on metabolic disturbances in women with polycystic ovary syndrome. Horm. Mol. Biol. Clin. Investig. 2017, 29, 85-91. [CrossRef] [PubMed]

279. Ardabili, H.R.; Gargari, B.P.; Farzadi, L. Vitamin D supplementation has no effect on insulin resistance assessment in women with polycystic ovary syndrome and vitamin D deficiency. Nutr. Res. 2012, 32, 195-201. [CrossRef] [PubMed]

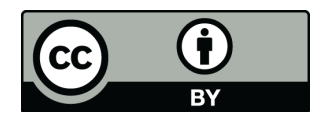

(C) 2018 by the authors. Licensee MDPI, Basel, Switzerland. This article is an open access article distributed under the terms and conditions of the Creative Commons Attribution (CC BY) license (http://creativecommons.org/licenses/by/4.0/). 